\title{
Are Japanese Firms Becoming More Independent from Their Banks?: Evidence from the Firm-Level Data of the "Corporate Enterprise Quarterly Statistics," 1994-2009
}

\author{
Yoshiro Miwa*
}

Professor, Faculty of Economics, Osaka Gakuin University, and Professor Emeritus of the University of Tokyo

\begin{abstract}
The Ministry of Finance's "Corporate Enterprise Quarterly Statistics" (Hojin kigyo tokei kiho) is the only statistical source of well-balanced information about the financing behavior of Japanese firms. Indeed, there are few comparable sources available anywhere in the world. Using this firm-level data set from 1994 to 2009, the author investigates the financing behavior of Japanese firms with over $¥ 10$ million in paid-in capital. The conclusions contrast sharply with the conventional wisdom.

Much of the research and policy discussions about Japanese finance begin from the premise that banks play a decisive role in firm behavior. This paper shows that firms have maintained a dependence on financial institutions well below the level that the conventional wisdom has claimed. Under the recent "zero-interest-rate, quantity easing" monetary policy, this "independence of the firms from the banks" has increased further. This tendency is clearest among the smaller firms. In turn, this first conclusion raises doubts about the plausibility of the basic premise of research and policy debate on financial issues, and leads us to question whether observers may not have confused a "crisis of financial institutions" with a "financial crisis". Investigation into firm financing behavior under the "financial crisis" from the end of 1997 to the beginning of 1999 does indeed suggest that it was a fiasco caused by the confusion of a "crisis of financial institutions" with a "financial crisis".
\end{abstract}

\footnotetext{
* Email: yoshiro.miwa1948@gmail.com. This is a revised version of the discussion paper with the same title (CIRJE-F-808, CARF-F-251, August 2011), which again is basically an English version of Miwa [2011b] in Japanese with the same title. It is based on a part of my "A Study of Financing Behavior of Japanese Firms with Firm-Level Data from Corporate Enterprise Quarterly Statistics - 1994-2009". I gratefully acknowledge the helpful comments and suggestions of Tomio Arai, Yoshitaka Fukui, Masazumi Hattori, Hidehiko Ichimura, Keimei Kaizuka, Takashi Kano, Motonari Kurasawa, Yusuke Narita, Kazuhiko Nishina, Takashi Obinata, Daisuke Tsuruta, Noriyuki Yanagawa, and other members of University of Tokyo CARF Financial System Research Forum, Wataru Ohta, J. Mark Ramseyer, and participants of seminars and workshops at The University of Tokyo, Osaka University, Ministry of Finance, and Bank of Japan. The research on which this article is based was supported by MEXT KAKENHI, Grant-in-Aid for Scientific Research (C) 20530192.
} 
Keywords: Corporate Enterprise Quarterly Statistics, "independence of Japanese firms from the banks", "financial crisis", "crisis of financial institutions"

JEL classifications: E44, E61, G21, G32, G33, N25

\section{Introduction}

It has long been the conventional wisdom about the Japanese firms and the economy that financial institutions, big banks in particular, dominate the financial markets where firm's financing behavior decisively depends on borrowing from the institutions. As the dominant view, they maintained an overwhelmingly strong influence on research and policy debates in related fields. This view even today, after the "Lost Two Decades" since the "Burst of the Bubbles", as a basic foundation has definitively conditioned the relevant research and policy debates.

The view, symbolically written in Hoshi and Kashyap [2001, p.310] that banks "were the only game in town", is widely accepted and remains as the conventional wisdom ${ }^{1}$ not only about the financial market in Japan before the (alleged) process of "financial liberalization" in the 1980s but also most Japanese firms at present with the exception of small number of exceptionally excellent big companies which are allowed to use bond markets effectively. ${ }^{2}$

Most issues that have long been repeatedly stressed as causes of the "Lost Two Decades" and its countermeasures, such as the banks' reluctance to lending (for small businesses) (kashi-shiburi)",3, the banks' delay in the disposal of bad loans (furyo-saiken) ${ }^{4}$, delay in improving the financial strength of financial institutions including banks, and (forced) increase in bank lending through continued quantitatively easing monetary policy, are all based on this conventional wisdom. We have been in a serious situation, if this conventional wisdom is based on factual errors and misconceptions and the position of financial institutions, large banks in particular, in the Japanese financial market and the roles they actually performed have been

\footnotetext{
${ }^{1}$ Corporations simply "did not have alternative sources of funding until the mid 1970s," explained Ito [1992, p.119]; "the domestic securities market was underdeveloped, and loans from abroad were not allowed." Consequently, "Japan's financial system was one of the most regulated and administratively controlled in the world" (Ito, 2000, pp.95-96). For a contrasting view, see Miwa and Ramseyer [2004].

${ }^{2}$ See Miwa and Ramseyer [2006] for the defects of the conventional wisdom about the Japanese economy which includes this view as a part.

3 Although widely used for a long time, as is usual the case, kashi-shiburi is terribly ill-defined.

4 Furyo-saiken and furyo-saiken-shori, although widely used even among academics, are terribly ill-defined, with which both academic discussions and political debates have long been miserably confused. On this point, see Miwa [2011c]. In this paper I use "bad-loans" for furyo-saiken rather than non-performing loans or "zombie lending", and also the "disposal of bad-loans" for furyo-saiken-shori rather than its "write-offs" or "allowances" as in Japan shori in this case usually includes both.
} 
substantially below the ones that the conventional wisdom has long claimed. Obviously, spending much time and energy in prescriptions and operations based on misdiagnoses comes at a heavy price. It is of absolute necessity, liberating us from the spell of a wrong conventional wisdom, to define problems and set agendas upon new assumptions and foundations for appropriate prescriptions and operations.

From early spring to late summer in 2010 I investigated the financing behavior of Japanese firms with over $¥ 10$ million in paid-in capital, using firm-level financial data from "Corporate Enterprise Quarterly Statistics" (Hojin kigyo tokei kiho; hereafter, CEQStat) of the Ministry of Finance. "A Study of Financing Behavior of Japanese Firms with Firm-Level Data from Corporate Enterprise Quarterly Statistics - 1994 2009”, divided into five discussion papers (Miwa, 2010b 2010f, hereafter DPI\&S and DP1 DP4), constitutes the report. ${ }^{5}$ The conclusions contrast sharply with the conventional wisdom. This paper is based on a part of the report.

In this research, the author investigates the financing behavior of firms, rather than lending behavior of financial institutions. Using firm-level data from CEQStat, a wide variety of issues are examined, including the validity of arguments which most existing research have long accepted as obvious and actively used as their common grounds. Some of the most basic grounds of the conventional wisdom about the Japanese financial phenomena are found to be false, upon which I designed and conducted new researches.

From this perspective, the most important finding of this research, which is also the most basic ground of this research, is the "Firm's Low 'Bank Dependence Ratio' (=borrowings from financial institutions/ total assets)" and "Recent Further Increase in 'Independence of Firms from Banks"" which is clearly observed during the study period since FY1994, ${ }^{6}$ after the turn of the century in particular. For instance, during the study period, firm-level data show that the ratio of firms with zero-bank-borrowing (irrespective of whether it is short-term, long-term, or their sum) is extremely high and has consistently increased in every size category. Among firms with non-zero borrowing the bank dependence ratio has consistently varied markedly, and has recently decreased in chorus. This tendency is more obvious among firms in smaller size categories where the firms are recognized to have no other sources of funding than banks than among larger firms some of which with "liberalization" have become able to rely heavily on capital markets.

This finding implies that one of the most basic assumptions of research and understanding of financial phenomena and policies and regulations related to financial markets has been a myth substantially deviating from the reality. As a part, the long-lasting policy debates about

\footnotetext{
${ }^{5}$ Miwa [2011a] is an English version of Miwa [2010b].

6 In Japan, "fiscal year (FY)" begins in April. This statistics surveys information about all the non-financial firms with over $¥ 600$ million in paid-in capital. In smaller size categories, it surveys randomly sampled firms.
} 
"banks' reluctance to (small business) lending, which symbolizes the "Lost Two Decades" (policy) controversy, might be groundless or based on a wrong assumption.

The firm's "bank dependence ratio" has been by far lower than the level the conventional wisdom has claimed, and in addition it has further decreased recently, which I call the "recent further increase in "Independence of Firms from Banks"'. With these findings emerge a series of questions: What was the reality of the "financial crisis" and "credit crunch" actualized from the end of 1997 to the beginning of 1999?; Did the government's policy responses work effectively?; Would the situation deteriorate into a grave crisis if left as it was?; and Wasn't the reality of the "financial crisis" only a "crisis of financial institutions"? Together with out-dated policy responses, isn't it inappropriate to call it a "fiasco"?

Much of the research and policy discussions about Japanese finance begin from the premise that banks play a decisive role in firm behavior. What occurs if this basic premise would shown to be a factual error, a myth substantially deviating from the reality? With the findings mentioned above, many basic questions, which have been set under seal, emerge as major study issues. First appear questions such as "was it appropriate as a national policy of the first order for a long time to force financial institutions prompt disposal of 'bad-loans'?", "how serious was the banks' reluctance to small business lending?, "was it really a serious policy concern?", and "was the traditional policy stance at first and at least to avoid bank failures?" Then come questions: "how and from where, besides financial institutions, firms, small firms in particular, raise capital? why they raise increasing ratio of capital from sources other than financial institutions?", and "what is the actual position of banks in the Japanese financial market and the role they perform?", "what is the function of trade credit, and its relation and division of roles with bank lending?"

The report on which this paper is based became huge and covers a wide range of topics, partly because the study went into some of those issues. Firstly, this paper reports the "firm's low "bank dependence ratio"" and "recent further increase in "independence of firms from banks", which are both the introduction to the study and its most basic finding, on which then I report the reality of the "financial crisis" during 1997-1999. Readers, stimulated by this paper interest in related issues, are expected to proceed to the report as a whole, focusing on the basic problem setting and the discussion.

Section II introduces the advantages of CEQStat data, and data and variables. Section III discusses the basic details of the "firm's low "bank dependence ratio"" and "recent further increase in "independence of firms from banks"'. Upon the discussion of Section III, Section IV investigates the reality of the "financial crisis" (fiasco). In Section V, as an illustration of the study of relationship among variables, I compare two groups of firms, including ones further increasing "independence of firms from banks" and the others non-increasing "independence". Section VI is for concluding remarks, with the list of "interesting observations" of the research to invite readers to the report on which this paper is based. 


\section{Data and Variables}

\section{Why Hojin kigyo tokei (Corporate Enterprise Statistics, CEStat), CEQStat in particular, is useful and informative?}

In the four points, CEQStat in particular, is an excellent and useful statistics that provides basic information about financing behavior of Japanese firms. Indeed, there are few comparable sources available anywhere in the world.

First, and above all, it provides information about financing behavior of firms that are on the demand side of financial market, rather than institutions in fund management like financial institutions on the supply side.

In discussing phenomena concerning economic confusion and stagnation of the Japanese economy during the "Lost Decade (or Two Decades)", even when focusing on firm behavior, financing behavior in particular, typically the basic perspective adopted along the conventional wisdom has focused on the supply side of funds, particularly lending behavior of financial institutions including banks that have been recognized to dominate it. However, it is obvious that the firm's source of funds is not limited to financial institutions (and shareholders).

Funds borrowed by firms (households, governments, or foreign agents) from financial institutions are not always all used for their own business activities such as production and facility investments (consumption, house construction, or various investments like R\&D). Some of the borrowed funds may be invested in the financial market, used in increasing trade credits or obtaining shares in finance companies, which are finally obtained by firms on the demand side of the financial market. Firms use financing necessary funds various financial markets where not only financial institutions but also many other types of agents including non-financial business firms that take part in. In order to understand adequately the firm's financing behavior, we should expand the focus of study from lending behavior of financial institutions to financial markets, and study their roles and functions. If financial institutions were reluctant to lend money to small businesses, as has been claimed earnestly in Japan, by way of financial markets money lent to other borrowers may finally reach those small businesses. We should focus on financing behavior of firms on the demand side of the markets rather than lending behavior of financial institutions on the supply side. For this purpose, CEStat, CEQStat in particular, is the most useful and informative. ${ }^{\text {? }}$

Second, CEStat (CEQStat) is the only random-sampled statistics in Japan that provides

\footnotetext{
7 For questions like "What is 'the banks' reluctance to lending?", "How serious has it been in Japan?", "What are the sources of trouble?", and "What can we and should we do?", see Miwa [2010a]. There may have been no such serious policy issues. Even when bank lending to small businesses has remarkably decreased, it may be because bank's business model has lost the comparative advantage in competition in the market or because it is inefficient.
} 
well-balanced balance-sheet information about financing behavior of firms on the demand side of financial markets. On small businesses in particular, it is the only reliable statistics.

Third, CEQStat surveys outstanding amount of items on firm's balance sheet both at the beginning and at the end of each quarter (each year for Nenpo, Annual Statistics), with which we see also the actual amount of change in financial items during each quarter (year), for instance from April to June. In contrast, most other data-sets like securities filings of listed firms, Policy Investment Bank of Japan, or CRD (Credit Rating Database) have a collection of firm's accounting (annual) reports. It is based on each firm's choice of accounting term (year), which inevitably varies among firms. This variation and difference in firms' accounting period actually surveyed might be a decisive constraint, with which those data-set will be fatally misleading in investigating the reality and impact of "financial crisis" (or "credit crunch"), for instance. CEQStat (CEStat) is free from this variation.

Fourth, firms raise funds from a wide variety of sources, and, as shown below, the ratio of funds from financial institutions like banks to the total assets has not been so high as is widely perceived. Traditionally, however, primary source of financial data have been provided by the Bank of Japan, most of which is collected from financial institutions, at least in the case of Japan. As a result, they place the greatest focus on the activities of financial institutions, like bank lending and deposit. A wide variety of financial activities and transactions in financial markets tend to be out of their direct concerns, and little information about so many important items on firm's balance-sheet is available in widely used financial data-set (or statistics). In contrast, by directly collecting data from financing firms, CEStat (CEQStat) provides rich information about items, which have been neglected or viewed as unimportant by the authorities and researchers of financial markets. In the research on which this paper is based, I also place focus on deposit, receivables, payables, and inventory.

\section{Advantage of firm-level data}

In addition to the points as mentioned above, this research enjoys an advantage of firm-level data. Reflecting various factors and constraints, financing behavior of firms is too complex and diverse to capture with aggregate values or sample mean values, assuming a representative firm in each size category. Although CEStat (CEQStat) collects useful and informative data, by publishing the results basically in aggregates values its potentials have not been fully exploited. ${ }^{8}$ By using firm-level data, I investigate the issues beyond the reach of aggregate value data, and find interesting results in detail.

Among the interesting results, it is the finding and verification with firm evidence of

\footnotetext{
${ }^{8}$ Obviously, aggregate values published in reports are quite informative, as shown in Section 8 of DP1 ([1-8]), but those published aggregate values have not fully utilized in the previous literature.
} 
phenomena, which I name "the Independence of Firms from Banks", particularly of small businesses, that I consider to have the most important direct impact on the research of financial markets in Japan. Only with the firm-level data is the source to find and confirm the phenomena.

The conventional wisdom, due to little interest of people including the financial authorities and researchers, argues roughly: "trade credit is a financing method for inventory fund". A simple study of the relationship between outstanding values of inventory and trade credits (receivables and payables) with firm-level data raises serious doubts to this view, however. By liberating ourselves from the spell of this kind of conventional wisdom, we will be able to begin a real study of firm's financing behavior, including trade credit and its relation with bank borrowings.

\section{Data and Variables ${ }^{9}$}

In this research I use firm-level data from the Corporate Enterprise Quarterly Statistics (CEQStat), with the exception of the parts on long-run trend where I use summary statistics from the Corporate Enterprise Annual Statistics (CEAStat). CEQStat classifies firms into 5 size categories, in the size of paid-in capital at the beginning of fiscal year. The five categories include 10 20, 20 50, 50 100, 100 1,000, respectively in million yen, and more than $¥ 1$ billion. Hereafter, I use notation from 5 to 9 , respectively, for each size category (v4). CEQStat calls the firms in the three smaller categories "small firms (literally, small and medium firms)", those which are in v4=8 "mid-sized firms", and those in v4=9 "big firms".

CEQStat is a sample survey, whose sample rates greatly differ across size categories. As a result, summary statistics over all the samples surveyed, depending on the sample rates and the sampling method, do not reflect the composition of population. CEQStat randomly samples approximately the following number of firms from each size category: v4 $=5,4,000$; v4 $=6$, 4,000; v4=7, 2,000; v4=8, 10,000 ${ }^{10}$; and v4=9, all firms.

For illustration, Table 1 shows the situation of the survey in the $3^{\text {rd }}$ quarter in FY2004.

Table 1. Situation of the Survey: 3rd Quarter of FY2004 (Oct.-Dec. in 2004)

\begin{tabular}{|c|r|r|r|r|}
\hline Paid-in Capital (¥million) & $10 \sim 99$ & $100 \sim 999$ & 1,000 & \multicolumn{1}{c|}{ total } \\
\hline Number of Firms Surveyed & 9,630 & 9,930 & 5,761 & 25,321 \\
\hline Number of Respondents & 6,584 & 8,129 & 5,333 & 20,046 \\
\hline Response rate (\%) & 68.4 & 81.9 & 92.6 & 79.2 \\
\hline
\end{tabular}

With the exception of the category for the big firms (v4=9) where survey is a census,

\footnotetext{
${ }^{9}$ For more details, see [I\&S-3] of Miwa[2011].

${ }^{10}$ In this category, actually all firms with more than $¥ 600$ million in paid-in capital are surveyed.
} 
CEQStat is a sample survey in which the samples surveyed are all renewed at the beginning of each fiscal year, at the beginning of April. All the sample firms are requested to report over 4 quarters on items (primarily financial items) both at the beginning and the end of the quarter. Therefore, with the exception of $\mathrm{v} 4=9$, firms surveyed in different fiscal years are basically different. On most firms surveyed, data only on 5 data points, including the data at the beginning of the $1^{\text {st }}$ quarter, are available.

In what follows I use notations like 200104, which stands for the $4^{\text {th }}$ quarter of FY2001, that is, January March 2002.

Basically in this research I use two types of variables, "level variables" and "difference variables". Suppose $y_{t}^{i}$ stands for the outstanding amount of financial item $i$ at time $t$, short-term borrowings from financial institutions, for instance, and $\mathrm{w}_{\mathrm{t}}$ the total assets. The first type of variables, level variables, $\mathrm{l}_{\mathrm{t}}^{\mathrm{i}}$, is $\mathrm{y}_{\mathrm{t}-1}^{\mathrm{i}} / \mathrm{w}_{\mathrm{t}-1}\left({ }^{*} 100\right)$, and the second one, $\mathrm{d}_{\mathrm{t}}^{\mathrm{i}}$, is $\left(\mathrm{y}_{\mathrm{t}-1}^{\mathrm{i}}-\mathrm{y}_{\mathrm{t}}^{\mathrm{i}}\right) / \mathrm{w}_{\mathrm{t}-1}$ $(* 100)$.

Note that I use the ratios of financial items, typically "level variables", $1_{\mathrm{t}}^{\mathrm{i}}$, like the ratio of short-term borrowings to total assets ("short-term bank dependence ratio"), at the beginning of the quarter, in which the ratio at 200104 stands for the one at the end of the $3^{\text {rd }}$ quarter in FY2001, at the end of December 2001. Therefore, $1_{t}^{i}=y_{t-1}^{i} / w_{t-1}(* 100)$. Also for "difference variables", $\mathrm{d}_{\mathrm{t}}^{\mathrm{i}}$, the ratio at 200104 stands for the ratio of change during the $4^{\text {th }}$ quarter in FY2001 to the total assets at the beginning of the 4th quarter in FY2001. Therefore, $d_{t}^{i}=\left(y_{t-1}^{i}-\right.$ $\left.\mathrm{y}_{\mathrm{t}}^{\mathrm{i}}\right) / \mathrm{w}_{\mathrm{t}-1}(* 100)$.

Table 2 shows the list of variables.

Table2. List of Variables

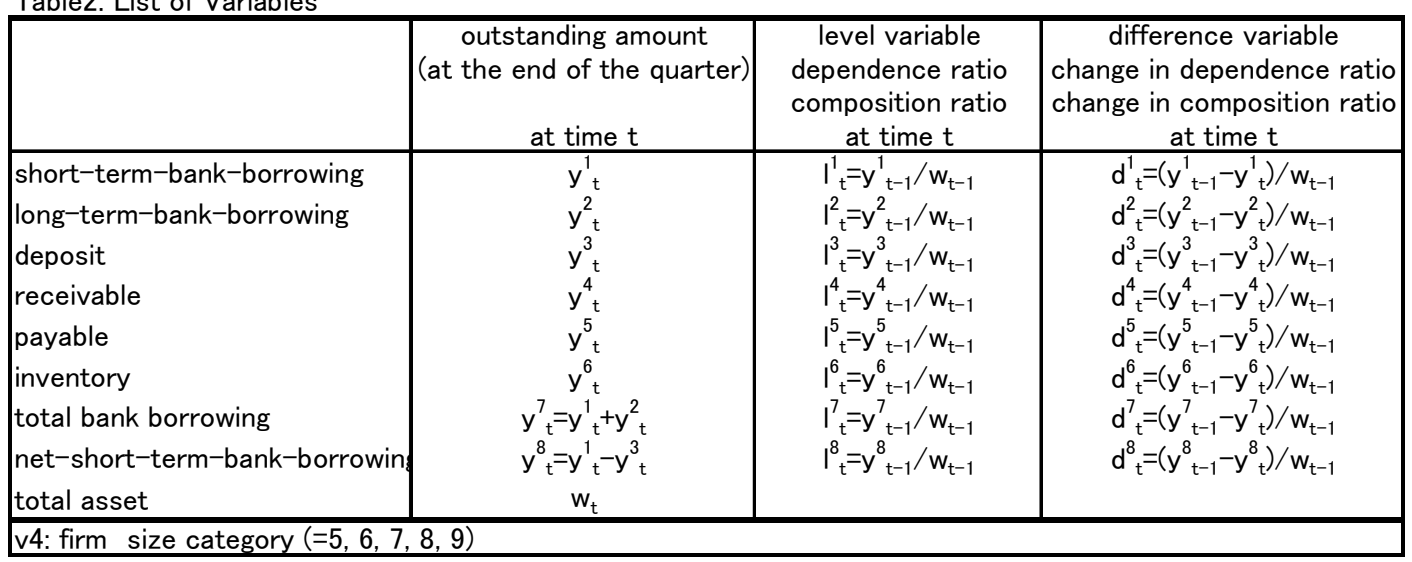

In CEStat, both CEQStat and CEAStat, classifies firms with the size of paid-in capital. For readers' convenience, I show below the average number of persons engaged in firms in each size category, first in all industries surveyed (Table 3a) and then in the manufacturing industry (Table 3b). Here, I show the picture for the third quarter of FY2004. Reader should note that, although it might be so serious for the main body of the research where I use firm-level data 
since FY1994, during the period since the 1960s over which I show an overview of long-run trends the correspondence between firm-size in paid-in capital and the one in the number of persons engaged has changed dramatically. Here, I follow the notations for firm size classification in CEQStat. 10 19 stands for $¥ 10$ million-20 million.

Table 3b. The Average Number of Persons Engaged in Firms: Manufacturing Industry

\begin{tabular}{|c|r|rrrrr|}
\hline \multicolumn{1}{|c|}{ total } & \multicolumn{1}{c}{$10^{*} 19$} & $20 \% 49$ & 5099 & $100 \% 99$ & \multicolumn{1}{c|}{ (unit: ¥million, number of persons) } \\
\hline Number of Firms (N) & 211,326 & 154,922 & 35,996 & 11,129 & 6,987 & 2,292 \\
\hline Number of Managers (M) & 608,684 & 402,211 & 112,776 & 39,295 & 30,965 & 23,437 \\
Number of Employees (L) & $9,259,530$ & $2,281,233$ & $1,495,042$ & $1,087,582$ & $1,364,876$ & $3,030,797$ \\
$\mathrm{M}+\mathrm{L}$ & $9,868,214$ & $2,683,444$ & $1,607,818$ & $1,126,877$ & $1,395,841$ & $3,054,234$ \\
\hline $\mathrm{M} / \mathrm{N}$ & 3 & 3 & 3 & 4 & 4 & 10 \\
$\mathrm{~L} / \mathrm{N}$ & 44 & 15 & 42 & 98 & 195 & 1,322 \\
$(\mathrm{M}+\mathrm{L}) / \mathrm{N}$ & 47 & 17 & 45 & 101 & 200 & 1,333 \\
\hline
\end{tabular}

The study period: from FY1994 to the $2^{\text {nd }}$ quarter of FY2009

Focusing on the "Credit Crunch" in 1997-1999, Miwa [2008] studied the data over seven years, from FY1994 to FY2000. The present research extends the study period to FY1994 the $2^{\text {nd }}$ Quarter of FY2009, 15 and half years. The world financial market has changed drastically, particularly since the second half of the 1990s, which is widely believed to be one of the causes of the "financial crisis" since the summer of 2007 and its protracting serious impacts. In relation to the turbulent days, particularly since the "Lehman Shock" in the fall of 2008, the reality and policy responses in Japan during the "Lost Two Decades", including the Japanese experience in its "Credit Crunch" in 1997-1999 gained a wide attention, often calling them cynically the "Japanese lessons". By extending the study period to the second quarter of FY2009, we can investigate its impacts on firm's financing behavior in Japan. In addition, we can investigate the effects of the long lasting "quantity easing monetary policy under zero-interest-rate".

For readers' and expositional convenience, I divide the study period from FY1994 to the $2^{\text {nd }}$ quarter of FY2009 into two parts, the first half of eight years up to FY2001 and the second half of seven and half years from FY2002, and in many cases I calculate the period average values. For example, as the long lasting "quantity easing monetary policy under zero-interest-rate" has been maintained throughout the second half period under which the "Independence of Firms from Banks" further increased, those comparisons would provide some hints for understanding its sources and mechanism. 


\section{The Low "Bank Dependence Ratio" and the Further Increase in "Independence of Firms from Banks"}

Section III is a summary of the basic part of Miwa [2010b], entitled "The Low 'Bank Dependence Ratio' and the Further Increase in 'Independence of Firms from Banks'”.

Most of research and policy discussions about Japanese finance begin from the premise that financial institutions, big banks in particular, have dominated the Japanese financial market and played there the key roles. This research begins with pointing out that this conventional wisdom is and has been a misunderstanding and misconception, a myth substantially deviating from the reality. As a result, from the beginning to end, this research has a wide variety of and grave implications both to research and policy discussions on Japanese finance.

\section{Number of zero-short-term-borrowing firms and its ratio to the total}

Emphasizing the relationship with the "banks' reluctance to lending", first of all, I focus here on firm's short-term borrowing ${ }^{11}$ from financial institutions. (Miwa [2010b] also investigates firm's long-term borrowing and total borrowing, that is, the sum of short-term and long-term borrowing.)

Here, I show the figure for the smallest firms' group ( $v 4=5$, Figure 1) and the list of group averages (Table 4, from [I-2-3], which indicates the corresponding part of the report, [I-2-3] for Section 2-3 of DP1, that is, Miwa [2010b]).

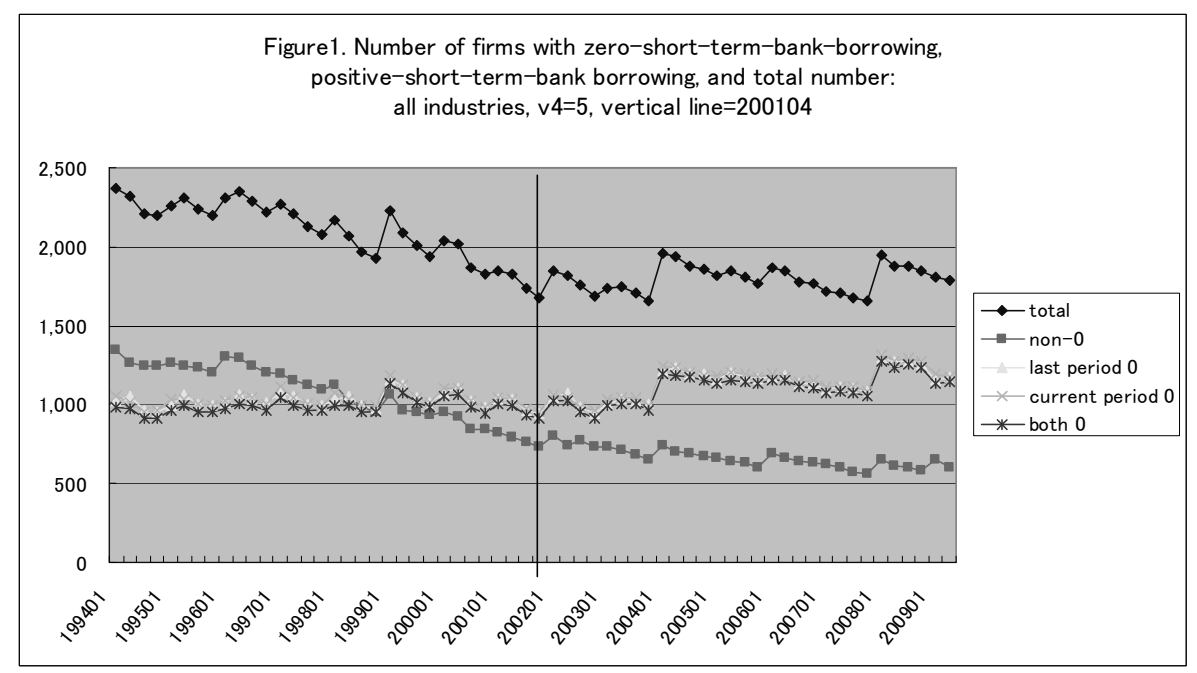

\footnotetext{
${ }^{11}$ Borrowing with remaining term less than a year is classified as "short-term", and otherwise as "long-term". Total borrowing is the sum of "short-term" and "long-term".
} 
Figure 1 shows the number of non-zero-short-term-borrowing firms (non-0) and zero-borrowing firms at the beginning of each quarter (last period 0), zero-borrowing firms at the end (current period 0), zero-borrowing firms both at the beginning and the end (both 0 ), and all the firms surveyed (total). For readers' convenience, a vertical line is placed on 200104, at the mid-period.

(1) Three numbers of zero-borrowing firms, at the beginning, at the end, and at both points of time, are always almost the same. It implies that most firms with zero-borrowing at the beginning end the quarter with zero-borrowing.

(2) The ratio of non-zero-short-term-borrowing firms has consistently fallen during the study period, to the level of the half around FY1998, and to the 1/3 in FY2009.

Table 4 lists the group average of ratios, for all firms and then for each size category. 0-0/T is the ratio of firms with zero-borrowing both at the beginning and end of the quarter to all the firms surveyed. I divide the survey period into two parts, until FY2001 and FY2002 and after, and show the average of ratios, as Average 1 and Average 2, respectively. Average $\mathrm{T}$ is for the whole period, and Av.1 - Av.2 is for their difference, that is, Average 1 - 2. It is the smallest firms' group (v4=5) where those ratios are the highest $(47.3,61.5,54.2)$ and the difference (Av.1 - Av.2) is the largest (-14.2).

Table 4. Ratios of the number of firms with zero-short-term-bank-borrowing both at the beginning and the end of the quarter, and of firms with zero-change in short-term-bank-borrowing during the quarter: averages by period and their differences

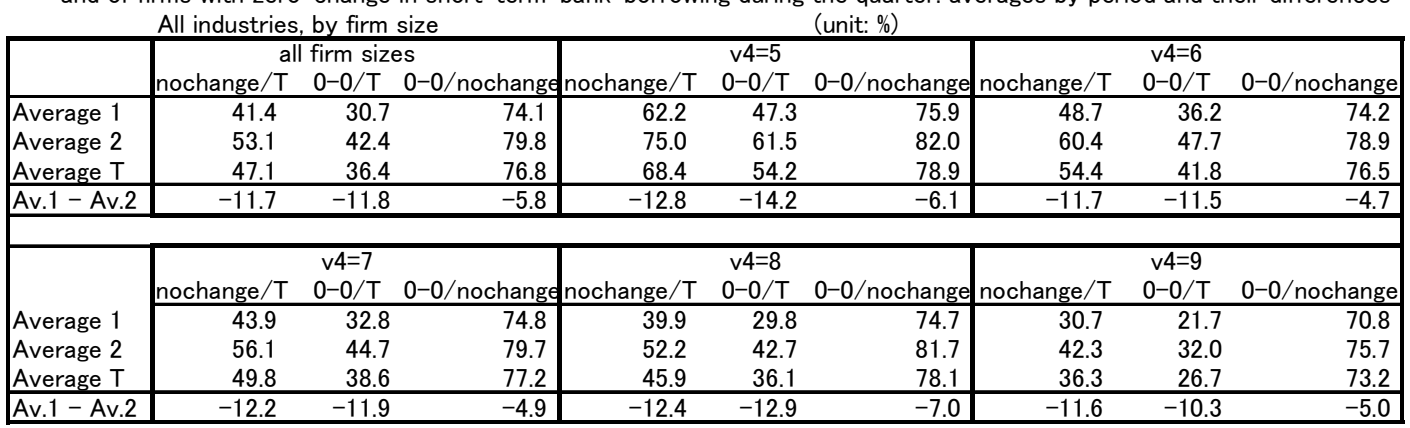

\section{Short-term bank dependence ratio $\left(l_{t}{ }_{t}\right.$}

From the cumulative distribution of firm's "short-term bank dependence ratio", the ratio of short-term-borrowing to total assets at the beginning of each quarter, I show the transition of p10, p25, p50, p75, p90 (p stands for percentile) in the following 3 figures, for all firms (Figure $2 \mathrm{a}$ ), for firms in $\mathrm{v} 4=5$ (Figure $2 \mathrm{~b}$ ), and $\mathrm{v} 4=8$ (Figure $2 \mathrm{c}$ ). All three figures consistently show that non-zero-short-term borrowing firms in every size category have constantly decreased the short-term bank dependence ratio. 

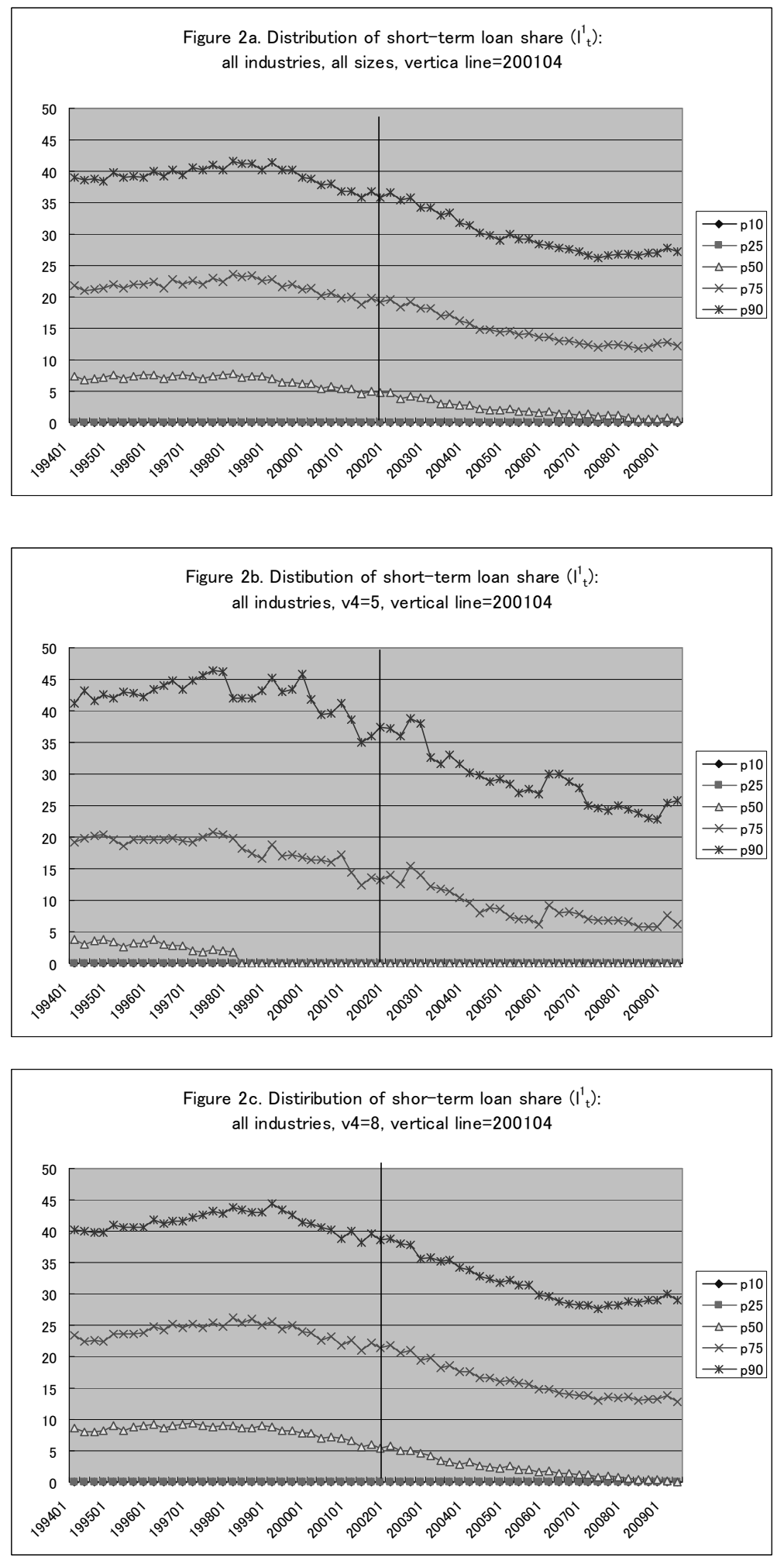
Table 5 shows the period averages of those percentile values, first for all firms and then for each size category. In every size category, the short-term bank dependence ratios of positive-short-term-borrowing firms fell during the study period.

Table 5. Distribution of short-term-bank-borrowing ratio $\left(\mathrm{I}_{\mathrm{t}}^{1}\right)$ all industries, by size

\begin{tabular}{|l|l|rrrrr|}
\hline \multicolumn{2}{|c}{} & $\mathrm{p} 10$ & $\mathrm{p} 25$ & $\mathrm{p} 50$ & $\mathrm{p} 75$ & $\mathrm{p} 90$ \\
\hline all firm szies & Average 1 & 0.00 & 0.00 & 6.79 & 21.67 & 39.25 \\
& Average 2 & 0.00 & 0.00 & 2.03 & 14.57 & 29.76 \\
& Average T & 0.00 & 0.00 & 4.49 & 18.23 & 34.66 \\
\cline { 2 - 7 } & Av.1-Av.2 & 0.00 & 0.00 & 4.76 & 7.11 & 9.49 \\
\hline \multirow{5}{*}{ v4=5 } & Average 1 & 0.00 & 0.00 & 1.56 & 18.09 & 42.31 \\
& Average 2 & 0.00 & 0.00 & 0.00 & 8.82 & 28.96 \\
& Average T & 0.00 & 0.00 & 0.80 & 13.60 & 35.85 \\
\cline { 2 - 7 } & Av.1-Av.2 & 0.00 & 0.00 & 1.56 & 9.26 & 13.36 \\
\hline v4=6 & Average 1 & 0.00 & 0.00 & 5.29 & 20.50 & 39.87 \\
& Average 2 & 0.00 & 0.00 & 0.72 & 14.32 & 31.34 \\
& Average T & 0.00 & 0.00 & 3.08 & 17.51 & 35.74 \\
\cline { 2 - 7 } & Av.1-Av.2 & 0.00 & 0.00 & 4.57 & 6.18 & 8.52 \\
\hline v4=7 & Average 1 & 0.00 & 0.00 & 6.17 & 20.97 & 38.70 \\
& Average 2 & 0.00 & 0.00 & 1.56 & 15.03 & 31.27 \\
& Average T & 0.00 & 0.00 & 3.94 & 18.10 & 35.10 \\
\cline { 2 - 7 } & Av.1-Av.2 & 0.00 & 0.00 & 4.61 & 5.94 & 7.43 \\
\hline \multirow{3}{*}{ v4=8 } & Average 1 & 0.00 & 0.00 & 8.19 & 23.92 & 41.35 \\
& Average 2 & 0.00 & 0.00 & 2.20 & 15.94 & 31.65 \\
& Average T & 0.00 & 0.00 & 5.29 & 20.06 & 36.66 \\
\cline { 2 - 7 } & Av.1-Av.2 & 0.00 & 0.00 & 5.99 & 7.98 & 9.70 \\
\hline \multirow{3}{*}{ v4=9 } & Average 1 & 0.00 & 0.29 & 7.56 & 20.13 & 34.81 \\
& Average 2 & 0.00 & 0.00 & 3.84 & 14.09 & 26.10 \\
& Average T & 0.00 & 0.15 & 5.76 & 17.21 & 30.59 \\
\cline { 2 - 7 } & Av.1-Av.2 & 0.00 & 0.29 & 3.71 & 6.05 & 8.71 \\
\hline
\end{tabular}

\section{Total bank dependence ratio $\left(l^{7}\right)$}

Concerning "total borrowing" (= short-term borrowing + long-term borrowing), I show the figure on the transition of total bank dependence ratio for the smallest firms (v4=5, Figure 3) and the summary table (Table 6) corresponding to Table 5 shown above (from I-2-5). What shown above is not peculiar to short-term bank dependence ratio, that is, the ratio of short-term borrowing. 


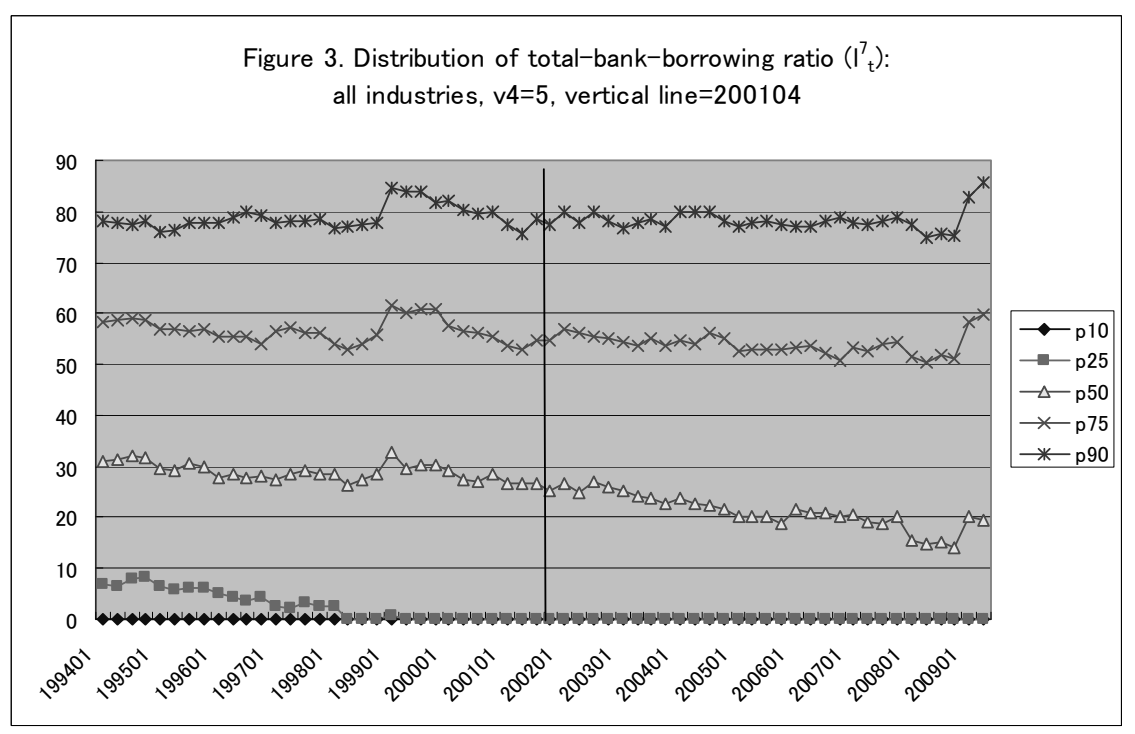

Table 6. Distribution of total-bank-borrowing ratio $\left(\mathrm{I}_{+}^{7}\right)$ : all industries, by size, unit $=\%$

\begin{tabular}{|c|c|c|c|c|c|c|}
\hline & & $\mathrm{p} 10$ & p25 & p50 & p75 & p90 \\
\hline \multirow[t]{4}{*}{ all firm sizes } & Average 1 & 0.00 & 2.88 & 25.81 & 51.06 & 73.03 \\
\hline & Average 2 & 0.00 & 0.00 & 14.64 & 40.47 & 63.04 \\
\hline & Average $T$ & 0.00 & 1.49 & 20.41 & 45.94 & 68.20 \\
\hline & $A v .1-A v .2$ & 0.00 & 2.88 & 11.17 & 10.59 & 9.98 \\
\hline \multirow[t]{4}{*}{$v 4=5$} & Average 1 & 0.00 & 2.69 & 28.79 & 56.60 & 78.79 \\
\hline & Average 2 & 0.00 & 0.00 & 21.00 & 54.01 & 78.31 \\
\hline & Average $T$ & 0.00 & 1.39 & 25.02 & 55.35 & 78.56 \\
\hline & $A v .1-A v .2$ & 0.00 & 2.69 & 7.78 & 2.59 & 0.48 \\
\hline \multirow[t]{4}{*}{$\mathrm{v} 4=6$} & Average 1 & 0.00 & 7.87 & 32.56 & 56.52 & 75.91 \\
\hline & Average 2 & 0.00 & 0.35 & 26.19 & 52.97 & 73.55 \\
\hline & Average $T$ & 0.00 & 4.23 & 29.48 & 54.80 & 74.77 \\
\hline & Av. $1-A v .2$ & 0.00 & 7.52 & 6.37 & 3.54 & 2.37 \\
\hline \multirow[t]{4}{*}{$\mathrm{v} 4=7$} & Average 1 & 0.00 & 5.28 & 32.26 & 56.10 & 76.42 \\
\hline & Average 2 & 0.00 & 0.00 & 23.52 & 51.04 & 71.06 \\
\hline & Average $T$ & 0.00 & 2.73 & 28.03 & 53.65 & 73.82 \\
\hline & $A v .1-A v .2$ & 0.00 & 5.28 & 8.74 & 5.06 & 5.36 \\
\hline \multirow[t]{4}{*}{$\mathrm{v} 4=8$} & Average 1 & 0.00 & 1.85 & 26.19 & 51.63 & 73.47 \\
\hline & Average 2 & 0.00 & 0.00 & 11.72 & 38.12 & 59.36 \\
\hline & Average $T$ & 0.00 & 0.95 & 19.19 & 45.10 & 66.64 \\
\hline & Av. $1-A v .2$ & 0.00 & 1.85 & 14.47 & 13.51 & 14.12 \\
\hline \multirow[t]{4}{*}{$v 4=9$} & Average 1 & 0.00 & 2.68 & 19.51 & 41.87 & 65.12 \\
\hline & Average 2 & 0.00 & 0.00 & 11.03 & 30.19 & 48.55 \\
\hline & Average $\mathrm{T}$ & 0.00 & 1.39 & 15.40 & 36.22 & 57.10 \\
\hline & $A v .1-A v .2$ & 0.00 & 2.68 & 8.48 & 11.68 & 16.56 \\
\hline
\end{tabular}

There are rather a small group of firms with extreme high total bank dependence ratio, in smaller firms' categories in particular,. For instance, the p 90 value for $\mathrm{v} 4=5$ remains at the level of almost $80 \%$, which however says that only $10 \%$ of firms in this category borrow more than 
$80 \%$ of their funds. In the second half-period, the p 25 value is 0 almost everywhere, and in the categories of $\mathrm{v} 4=7 \sim \mathrm{v} 4=9$ the ratios remarkably fell everywhere as shown in Av.1 - Av.2.

\section{Net short-term bank dependence ratio $\left(l^{8}\right)$}

Bank borrowing, including short-term bank borrowing, is a part of firm-bank trade relationship. In this light, Miwa [2010b] (I-5 I-6) focuses on deposits (and cash). During the study period, although "Bank Dependence Ratios" remarkably fell, the ratio of deposit to total assets remained at the same level, or rather moved upwards (I-4).

Firms hold deposits for various purposes, and in Miwa [2010b] I focus on deposit from various perspectives. If a particular attention is paid to short-term confusion in financial market such as "credit crunch", "financial panic", or drastic tightening, it might be recognized that the deposit is shown as a buffer for them and with interests in the level and movement of the net short-term bank dependence ratio, that is (short-term bank borrowing minus deposit)/total assets.

Here, I introduce part of the results on this new short-term bank dependence ratio. The following is the figure on the transition of net short-term bank dependence ratio for the smallest firms (v4=5, Figure 4 ) and the summary table (Table 7 ) corresponding to the above Table 5 (from I-5-2).

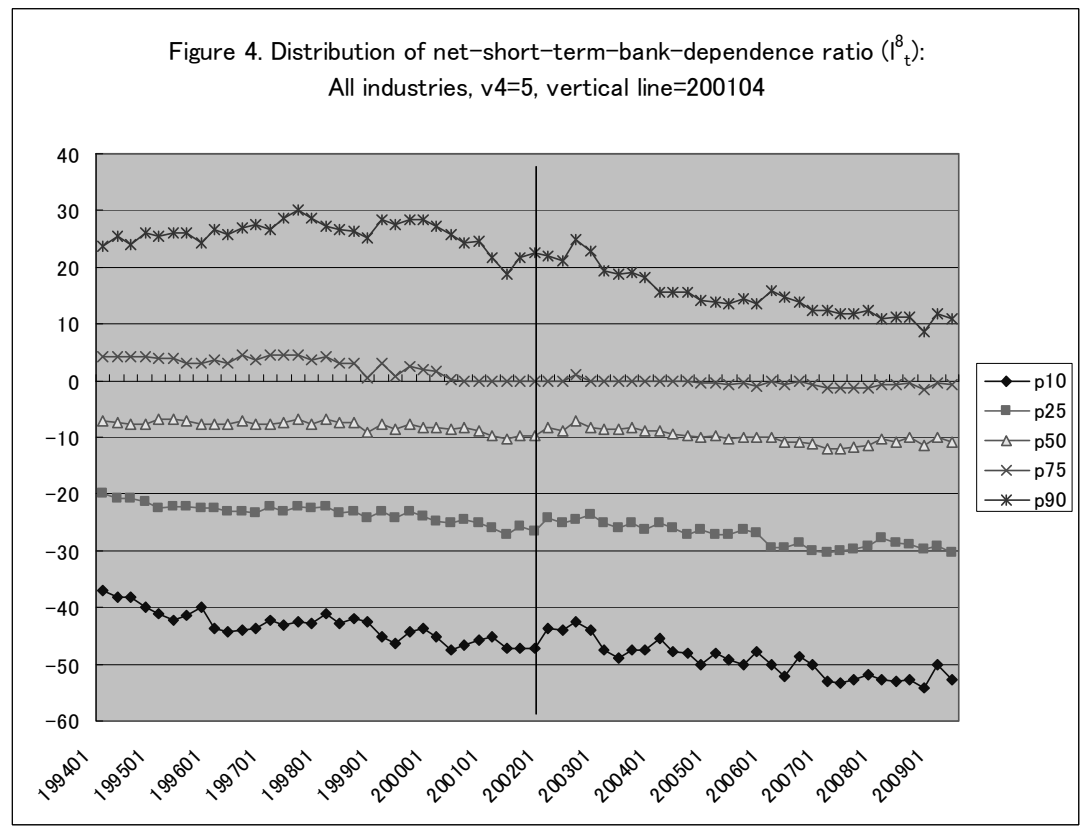

The p75 value almost remained at the level of $0 \%$, which means that only $25 \%$ of firms in this size category hold short-term borrowing larger than their bank deposit. The p90 value is at 
the level of $10 \%$ recently.

Table 7 shows that the above is not peculiar to firms in $\mathrm{v} 4=5$. By net short-term bank dependence ratio, firms' "Bank Dependence Ratio" has not been so high as the conventional wisdom has argued, and recently their "Independence from Banks" has further increased remarkably.

Table 7. Distribution of net-short-term-bank-borrowing ratio $\left(\mathrm{l}_{\mathrm{t}}^{8}\right)$ : all industries, by size

\begin{tabular}{|c|c|c|c|c|c|c|}
\hline & & $\mathrm{p} 10$ & p25 & p50 & p75 & p90 \\
\hline \multirow[t]{4}{*}{ all firm sizes } & Average 1 & -27.45 & -11.49 & -0.98 & 12.34 & 30.39 \\
\hline & Average 2 & -34.02 & -15.55 & -3.05 & 5.56 & 21.51 \\
\hline & Average $\mathrm{T}$ & -30.63 & -13.45 & -1.99 & 9.06 & 26.09 \\
\hline & Av.1 - Av.2 & 6.57 & 4.06 & 2.07 & 6.77 & 8.89 \\
\hline \multirow[t]{4}{*}{$v 4=5$} & Average 1 & -43.28 & -23.32 & -7.93 & 2.64 & 25.83 \\
\hline & Average 2 & -49.31 & -27.45 & -9.97 & -0.40 & 15.10 \\
\hline & Average $\mathrm{T}$ & -46.20 & -25.32 & -8.92 & 1.17 & 20.63 \\
\hline & $A v .1-A v .2$ & 6.02 & 4.13 & 2.03 & 3.04 & 10.73 \\
\hline \multirow[t]{4}{*}{$\mathrm{v4}=6$} & Average 1 & -36.16 & -18.74 & -5.40 & 5.74 & 24.68 \\
\hline & Average 2 & -43.33 & -23.52 & -8.14 & 1.19 & 17.89 \\
\hline & Average $T$ & -39.63 & -21.05 & -6.72 & 3.54 & 21.39 \\
\hline & Av.1 - Av.2 & 7.17 & 4.79 & 2.73 & 4.55 & 6.78 \\
\hline \multirow[t]{4}{*}{$v 4=7$} & Average 1 & -29.09 & -13.36 & -2.54 & 9.08 & 27.27 \\
\hline & Average 2 & -35.81 & -17.73 & -4.73 & 3.60 & 21.02 \\
\hline & Average $T$ & -32.34 & -15.48 & -3.60 & 6.43 & 24.24 \\
\hline & $A v .1-A v .2$ & 6.71 & 4.37 & 2.19 & 5.48 & 6.25 \\
\hline \multirow[t]{4}{*}{$\mathrm{v} 4=8$} & Average 1 & -23.39 & -8.65 & 0.00 & 15.34 & 33.58 \\
\hline & Average 2 & -32.82 & -14.25 & -2.29 & 6.75 & 23.86 \\
\hline & Average T & -27.95 & -11.36 & -1.11 & 11.18 & 28.88 \\
\hline & Av.1 - Av.2 & 9.42 & 5.60 & 2.30 & 8.59 & 9.73 \\
\hline \multirow[t]{4}{*}{$\mathrm{v} 4=9$} & Average 1 & -18.98 & -7.24 & 0.72 & 14.02 & 29.55 \\
\hline & Average 2 & -22.21 & -9.43 & -0.79 & 8.12 & 20.89 \\
\hline & Average $T$ & -20.54 & -8.30 & -0.01 & 11.16 & 25.36 \\
\hline & Av.1-Av.2 & 3.23 & 2.18 & 1.51 & 5.90 & 8.66 \\
\hline
\end{tabular}

\section{Long-run trend}

The period of the study with firm-level data is from FY1994 to the second quarter of FY2009. Not a few readers might wonder if the conclusion also applies to the period before the study period, for instance to the 1960s and the 1970s, as the Japanese economy had changed drastically through "liberalization" in the 1980s, and the "Bubble" in the second half of the 1980s and its burst in the 1990s. Readers should ask themselves on what logical grounds and evidences the conventional wisdom is founded and supported. CEStat has been almost the only well-organized and balanced statistical data on firm's financing behavior, and this statistics has rarely been actively used for its study.

Assuming a question, "how was the firm's financing behavior before the study period?", in 
[I-7], using summary statistics from CEAStat, the following explains the long-run trend of key financial variables ("level variables") since FY1960. ${ }^{12}$

For instance, for firms from $¥ 10$ million to $¥ 50$ million in paid-in capital that corresponds the CEQStat's v4=5 and 6, the short-term bank dependence ratio started with the level below $20 \%$ and until very recently remained around $15 \%$ level, which has not been remarkably different from that of bigger firms. As the long-term bank dependence ratio remained around $10 \%$ everywhere (I-7-3), the total bank dependence ratio was not so high as the conventional wisdom argues.

The ratio of receivables to total assets, "receivable dependence ratio" $\left(1^{4}\right)$, is the most impressive. Here, the results are on all industries (I-7-6-1). In the 1960s and 1970s this ratios were at the level of $30 \%$ everywhere, which were higher than the short-term bank dependence ratios. In the $2000 \mathrm{~s}$, a group of firms in the business scale from $¥ 10$ million to $¥ 50$ million is slightly above $15 \%$, approximately the half of the 1960 s level, which is lower than that of bigger firms.

This is the receivable dependence ratio, rather than the payable dependence ratio. In the 1960s, the heyday of the "dual structure" theory, large firms with advantageous position in the market supplied (relent) to smaller firms as trade credit, the conventional wisdom argues. Their receivable dependence ratio, however, was at almost the same level as the one of small businesses. It is small businesses rather than large firms that decreased this dependence ratio remarkably, through the process of "liberalization" and development in financial market.

\section{The Reality of the "Financial Crisis and Credit Crunch" (Fiasco)}

Section IV is a summary of the basic part of Miwa [2010c], entitled "The Reality of Short-term Shocks like the 'Credit Crunch' of 1997-1999 and the 'Financial Crisis' of 2007, and the Effectiveness of 'Emergency' Economic Measures - A Follow-up to Miwa [2008]'. As a follow-up to Miwa [2008], in Miwa [2010c] I investigate the reality of the "credit crunch" of 1997-1999 in a wider perspective. Also, I study the influence both of various "emergency economic measures" adopted as countermeasures and of the ultra-easy credit policy that has lasted after the "crunch". I focus as well on the influence of the recent "financial crisis" of 2007.

In Miwa [2008], I investigated individual firm's financing behavior, including borrowings from financial institutions, during the "financial crisis" or "credit crunch", from the end of 1997 to the beginning of 1999 in particular. For this purpose, firm-level financial data was studied for approximately 6,000 non-financial firms with more than $¥ 600$ million in paid-in capital from CEQStat financial data, from FY1994 to FY2000. The present research extends the study

${ }^{12}$ For a brief summary of this part, see [I\&S-4] of Miwa [2011]. 
period to FY1994 the $2^{\text {nd }}$ Quarter of FY2009.

The conventional wisdom argues that there was a serious "credit crunch" in Japan during this period, particularly between the end of 1997 and the beginning of 1999. I examined the short-term variations (quarter, semi-annual, and annual) in not only of bank borrowings (short-term borrowing, long-term borrowing, and total borrowing) but also of payables, receivables, deposits, and inventory, and also correlations between those financial variables. I found, however, no clear sign of serious "credit crunch". It is unclear on what ground the conventional wisdom is based, and little empirical supporting evidence is presented. ${ }^{13}$ From this observation, this report concludes not to accept the argument that during the period from the end of 1997 to the beginning of 1999 there was a serious "credit crunch" in Japan. With its non-existence it was found that the "policies" alleged to be adopted for its prevention and alleviation were ineffective.

No serious criticism or rebuttal statement has appeared since the publication of Miwa [2008]. In the discussion on the development and countermeasures toward the worldwide "financial crisis (or panic)" that became obvious since July 2007, not a few argued to learn from the Japanese experiences (including policy failures) of a decade ago. If the suggested Japanese "experiences" is the conventional wisdom that is based on misconceptions and misunderstanding on the basic facts of the reality both of the "financial crisis" that actually occurred in Japan and of adopted countermeasures and their effectiveness, misunderstandings might lead to another more grave confusion and tragedy (or comedy). ${ }^{14}$

In size categories smaller than $¥ 600$ million in paid-in capital, at the beginning of each fiscal year (in April), CEQStat randomly selects all the firms to survey, and Miwa [2008] focused on firms with firms with larger than $¥ 600$ million in paid-in capital. Because of this circumscription, there remains a strong interest in a question: "Does the same conclusion apply

${ }^{13}$ For the details on this point, see pp.14 21 of Miwa [2008]. Observers have often referred to the DI (Diffusion Index) on "lending position of financial institutions" provided by the Bank of Japan as a supporting evidence of the serious "credit crunch". I wrote there (p.18) as follows. The third point is the most important. "Do the questionnaire and the firm's responses on which the DI is based include relevant and appropriate information positive users of this DI presume?" After careful examination, few would answer "YES" to this question, I predict. Unless being able to answer "YES" to this question, it must be impossible for reader to accept, upon a chart of this DI's movement, the conventional wisdom that there was a serious "credit crunch". For more details of critically reviewing DI discussions, see Section IX of Miwa [2011c].

14 The conventional wisdom, dominant at least in Japan, argues that the recent "financial crisis" had influenced only slightly, if any, the Japanese economy, which differs substantially from that of the "financial crisis" or the "credit crunch" at the end of the 1990s. However, as shown in Miwa [2008] in Japan during 1997 1999 there was no clear sign of serious influence of the "credit crunch", and during the recent "financial crisis" I find in every size category of firms a dramatic decrease both in receivables and payables, particularly in the third quarter of FY2008, that is immediately after the "Lehman Shock". If we classify it as part of the "shadow banking system", Japan suffered its serious contraction, we should say. 
also to smaller firms with less than $¥ 600$ million in paid-in capital? Is the situation different?’

Some seem to be frustrated, arguing: "it was credit crunch or banks' reluctance to small businesses lending that was serious during that period, and it is off target like this study to focus only on large companies." As shown in Section II, in 2004 the average number of employees in firms in category between $¥ 100$ million- 1 billion paid-in capital was below 200 , and with more than $¥ 1$ billion was slightly more than 1,000 . Neither persuasive theoretical ground nor powerful empirical evidence has been presented to support and confirm the validity of the conventional wisdom. "There was a serious credit crunch, particularly to small businesses." In Miwa [2008, pp.154-56], I tentatively countered to this kind of argument.

The primary focus of this research is placed on small businesses rather than on big enterprises. Little well-balanced information has been presented concerning financing behavior of Japanese small businesses including borrowings from financial institutions, and therefore few know it in detail and accurately. With the two reasons, in this research, I summarize basic information about financing behavior of Japanese firms, focusing on small businesses.

As smaller firms with less than $¥ 600$ million in paid-in capital surveyed are replaced every fiscal year, we cannot conduct completely the same investigation with firms in smaller size categories as in Miwa [2008].

\section{Influence of and countermeasure to the situation that there were so many zero-short-term-bank-borrowing firms}

Particularly in smaller firm groups there were so many zero-short-term-bank- borrowing firms, whose ratio further increased during the study period. Most firms with zero-short-term-bank-borrowing at the beginning of the quarter remain the same at the end. Under such a situation, where the ratio of those firms is more than a half, the basic measure of this research, also adopted in Miwa [2008], to focus on the distribution of short-term-bank-borrowing "difference variable", the ratio of change in short-term- borrowing during the quarter to total assets at the beginning, might face serious troubles. In addition, there must be non-zero-short-term-borrowing firms with 0 change simply because of borrowing period longer than a quarter.

Table 3 in Section III shows also nonchange/T and 0-0/nonchange. The former is the ratio of the number of firms with non-change to all firms, and the latter is the ratio of firms with zero-short-term-borrowing both at the beginning and the end to the number of non-change firms. Among the smallest firms in $\mathrm{v} 4=5$, for instance, in the second half period, the former was $75 \%$, and the latter was $82 \%$. Then, such a dominance of $0-0$ firms might seriously affect the studies with short-term-bank-borrowing "difference variable".

For example, if we draw a conclusion, there were few small businesses which were obliged to reduce and actually reduced borrowings from financial institutions even during the 'credit 
crunch' period", we have to prepare ourselves to accept a criticism. It might be a false observation or an illusion that comes up with a dominance of information about the firms that had completed their 'Independence from Banks' over that about firms with non-zero-bank-borrowing. Cleaning up such a noise, we have to focus on firms that needed to borrow from financial institutions."

As shown in Figure 5, the ratio of non-zero-short-term-bank borrowing firms was lower in smaller firm group. It fell drastically in every group during the study period.

Nonetheless, by focusing only on firms with more than $¥ 600$ million in paid-in capital and limiting the study period to FY1994 - FY2000, fortunately, its influence to the conclusion of Miwa [2008] seems to be relatively minor.

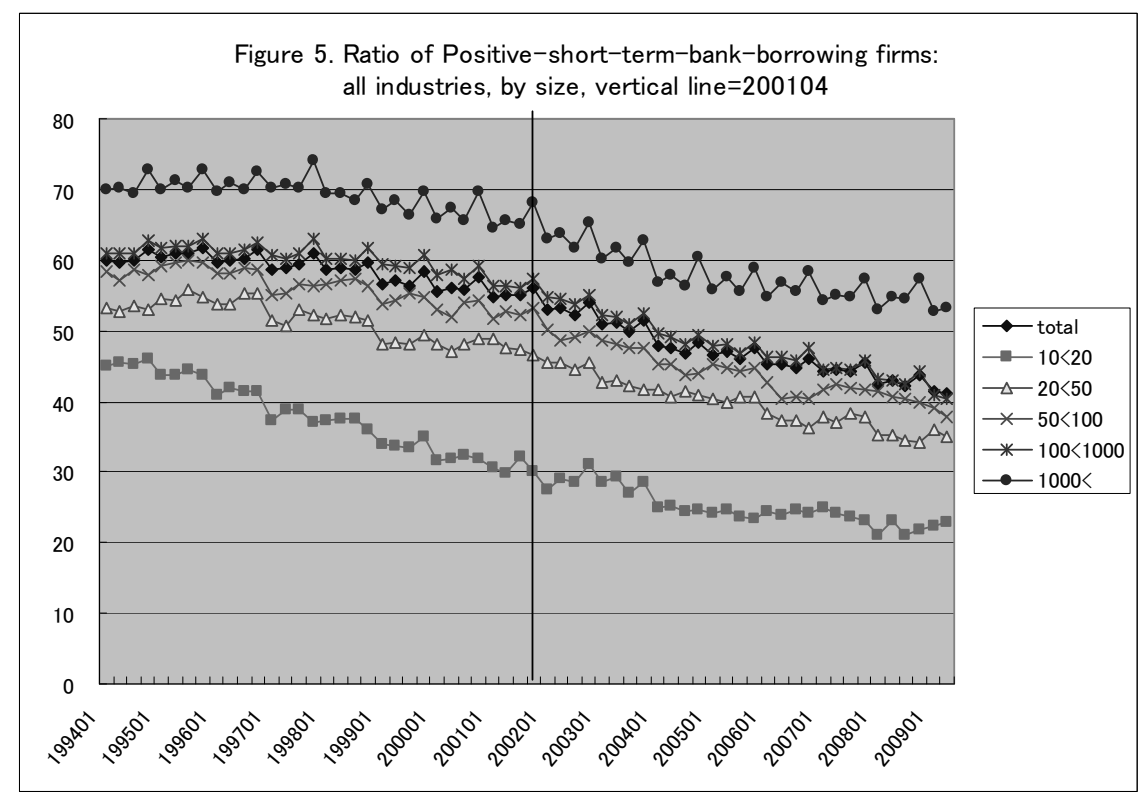

Figure 6 shows the transition of values of p10, p25, p50, p75, and p90 for the distribution of short-term-bank-borrowing "difference variable". Actually, most probably due primarily to the influence in the ratio of non-change firms, the distribution seems to be rapidly concentrating around 0 value, like "collapsing" from both sides. This figure is about all the firms in all industries. 


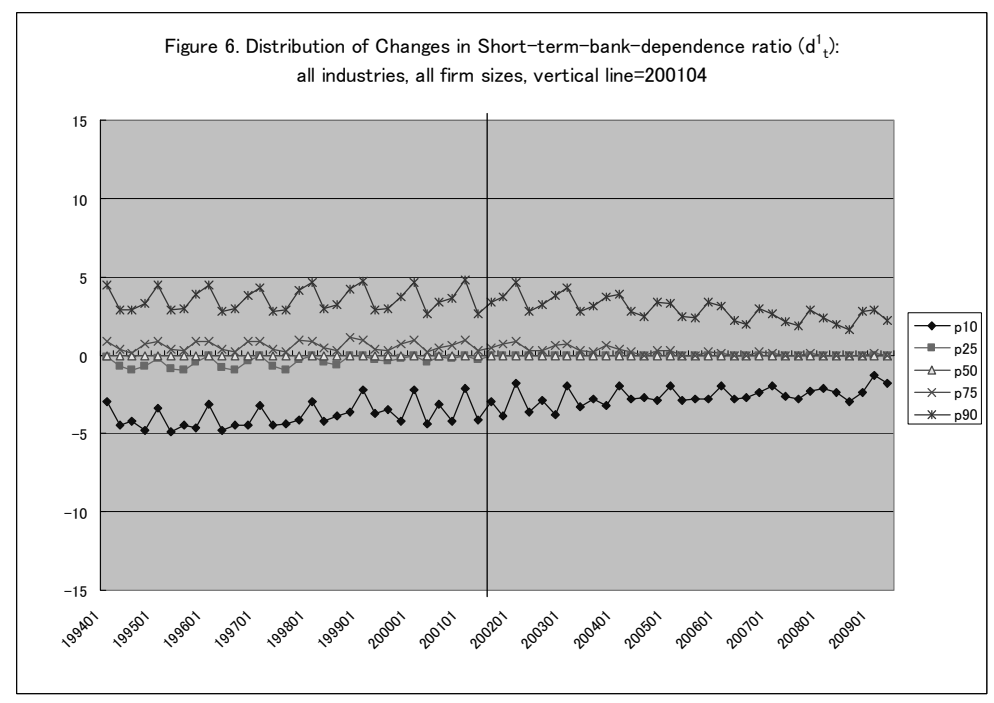

I tried two countermeasures: the first is to exclude firms with zero-short-term- borrowing at the beginning of the quarter (Modified Sample 1); and the second is to exclude firms with non-change in short-term-borrowing (Modified Sample 2). Confirming that those two countermeasures draw similar results, mostly in thie research I took the first one (Modified Sample 1).

\section{“Credit Crunch"?: a follow-up of Miwa [2008]}

Figure 7a shows the distribution of short-term-bank-borrowing "difference variable" for firms in v4=5, with Modified Sample 1 (II-3-1).

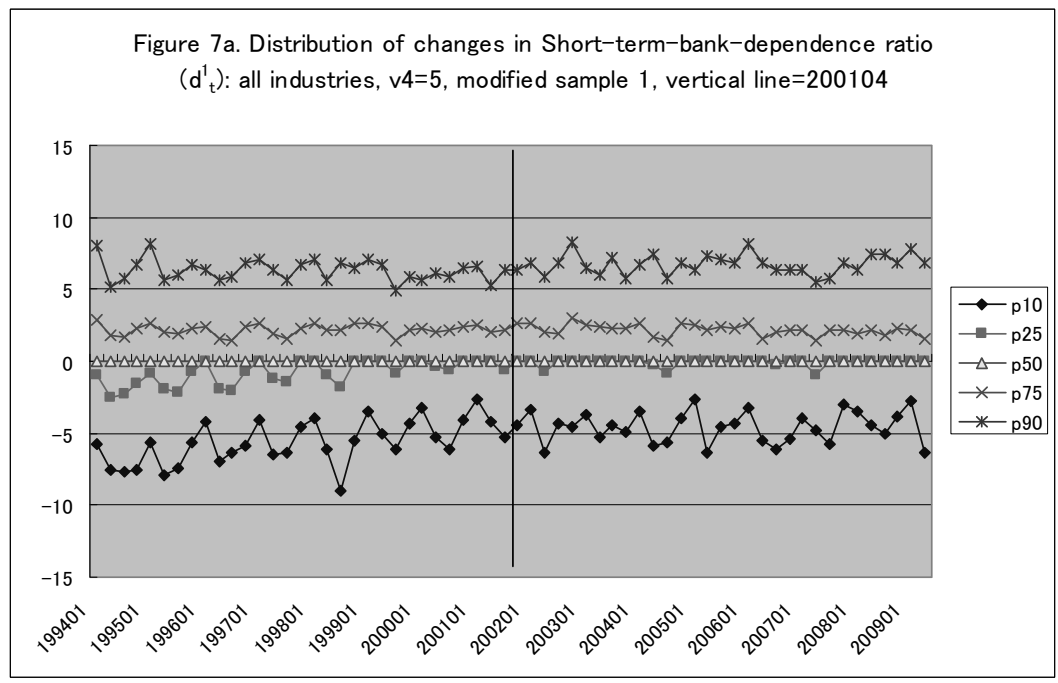


What is prominent here is the shift of distribution in the $3^{\text {rd }}$ quarter of FY1998, suggesting a drastic increase in small firm's borrowing, which is most probably a consequence of temporary explosion of their borrowing stimulated by "the Special Credit Guarantee Policy" for small businesses that began in October 1998 and ended in March 2001.

Figure $7 \mathrm{~b}$ is the corresponding one for $\mathrm{v} 4=8$. As the "Policy" was for small businesses, there is no such a drastic shift in $199803 .{ }^{15}$ (Hereafter, often I show figures for v4 $=5$ and 8 , the former for representative of small businesses and the latter for larger firms.)

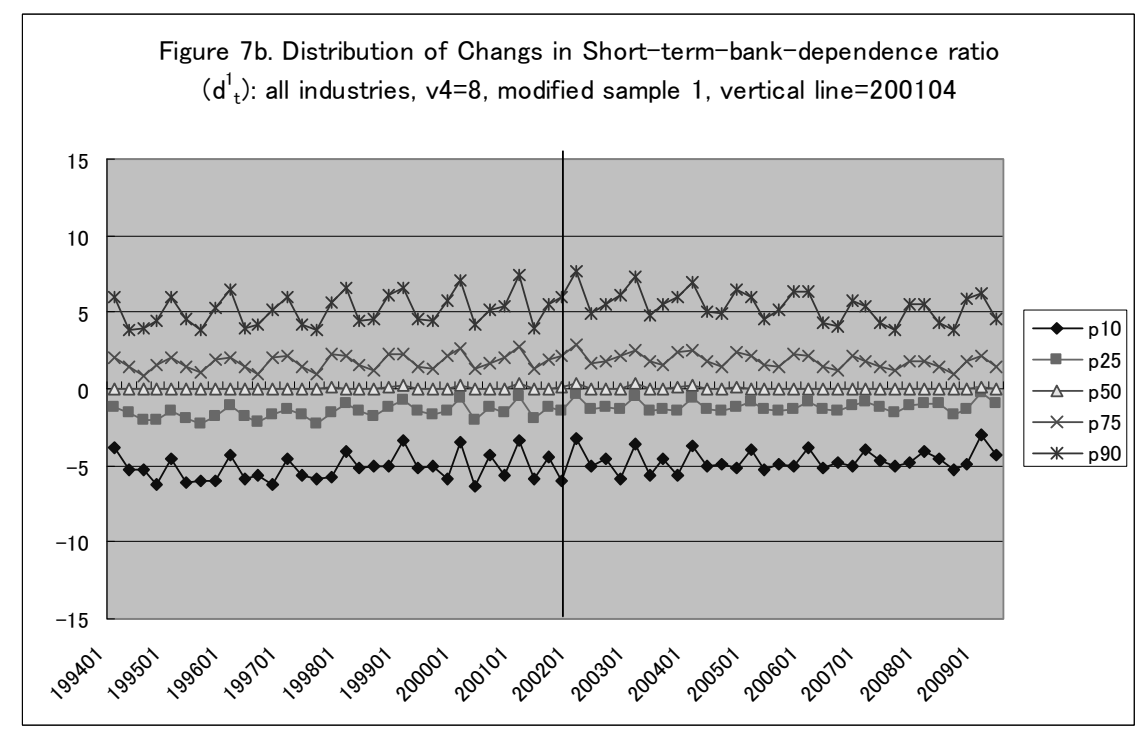

Distribution of level variables $\left(l_{t}^{i}\right)$ :

The ratio of receivables, payables, or inventory to total assets

From the second half of Miwa [2010c] to Miwa [2010e], I expand the examination items from transaction items with financial institutions like borrowing and deposit to a wider variety of balance-sheet items. The major focus is placed on receivables and payables, and also inventory often alleged to be closely connected with them. [II-6] and [II-7] focus on the level variables, the ratio of receivables, payables, or inventory to total assets, and [II-8] [II-11] on the difference variables, the ratio of change in deposits, receivables, payables, or inventory to total assets.

The primary purpose of the second half of Miwa [2010c] is to organize the basic

${ }^{15}$ For the details of this Policy, see Miwa [2010a]. Under this policy scheme, it was profitable to borrow in long-term, 5 to 7 years. The shift of distribution is more prominent in corresponding figures on long-tem borrowing, shown in [II-4-1] and [II-5-2]. The shift is clearly observed in figures both for v4=5 and 6 , nothing for $v 4=8$ and $\vee 4=9$, and a slight shift for $v 4=9$, for firms with $¥ 50 \sim ¥ 100$ million in paid-in capital. 
information. ${ }^{16}$ For illustration, I introduce here, for $\mathrm{v} 4=5$ and 8 , the distribution of the ratio of payable to total asset $\left(1_{t}^{5}\right)$, that is (might be) close substitute for bank borrowing (Figure $8 \mathrm{a}$ and Figure 8b, II-6-2).
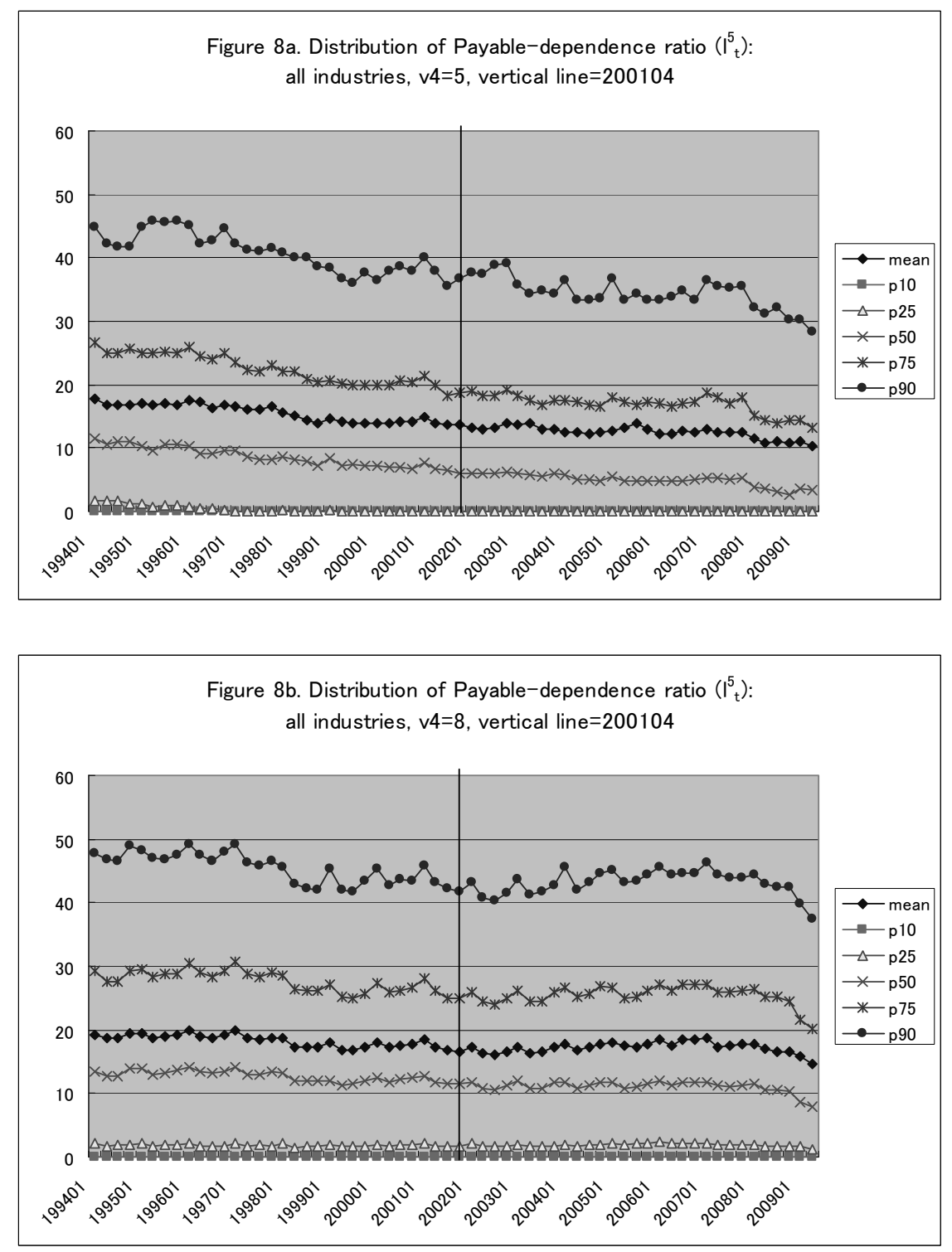

In either class, the ratio has been widely distributed, and it has been consistently lower in $\mathrm{v} 4=5$ than in $\mathrm{v} 4=8$. What those figures show is far from the schematic unilateral relation in the conventional wisdom that small business has obtained credit from large firms through

\footnotetext{
${ }^{16}$ On the position and role of trade credit in the Japanese financial market and in financial market in general and its relation with bank borrowing, see Miwa and Ramseyer [2008].
} 
payables.

Rapid decrease in the payable/(total asset) ratio during the recent "financial crisis", not during the former "credit crunch", is prominent. The same applies also to the receivable/(total asset) ratio (II-6-1). The reason and mechanism are unexplored, yet.

The ratio of inventory to total asset has been consistently much lower than either the receivable/(total asset) ratio or the payable/(total asset) ratio. In addition, unlike the latter two ratios, during the recent "financial crisis", the inventory/(total asset) ratio has not decreased (II-7). The conventional wisdom that trade credit has been used for inventory finance will be under pressure for reevaluation.

The above holds with little modification when I limit the examination to the manufacturing sector.

\section{Distribution of difference variables $\left(d_{t}^{i}\right)$}

In [II-8] [II-11], I examine the distribution of difference variables $\left(\mathrm{d}_{t}^{\mathrm{i}}\right)$, the ratio of change in deposits, receivables, payables, or inventory to total assets, respectively.

The following illustrates $\mathrm{v} 4=5$ and 8 , the distribution of the ratio of change in payable to total asset $\left(d^{5}\right.$, Figure $9 a$ and Figure $9 b$, II-10-1).

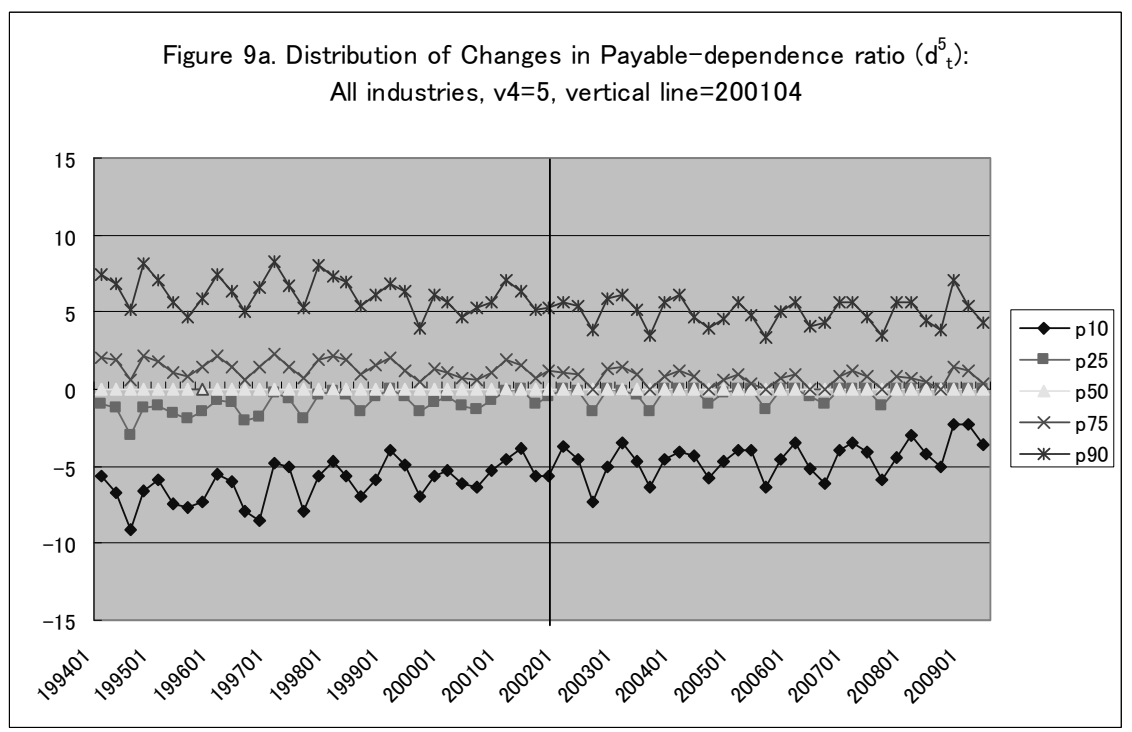




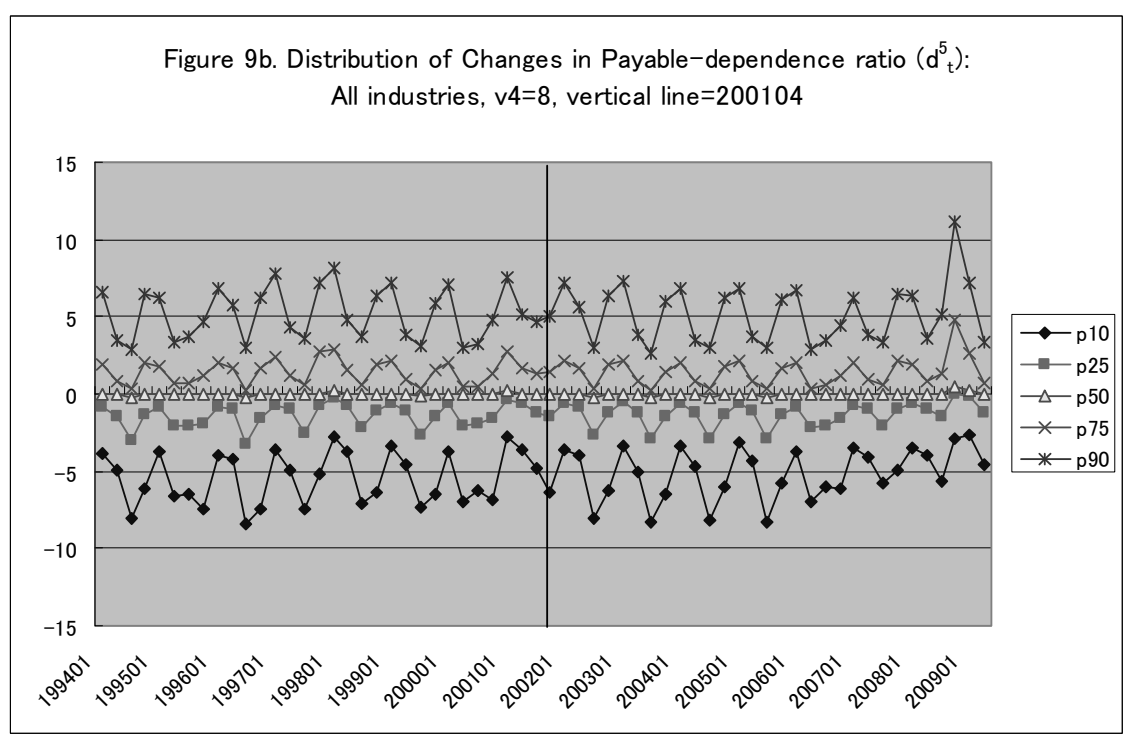

In either class, the ratio has been widely distributed. Nowhere I find a prominent movement of the distribution of change in payable dependence ratio, for instance, in that of small businesses during the "credit crunch" or at the third quarter of FY1998.

The distribution of change in inventory dependence ratio, the ratio of change in inventory to outstanding total asset, shows that its movement is by far smaller than that of receivables or payables. The close relationship between inventory and trade credit, that is, receivables and payables. Thus, the conventional wisdom, that takes it obvious and for granted, is unclear (for the details see Miwa [2010e]). The conventional wisdom that trade credit has been used for inventory finance will be under pressure for reevaluation.

The conclusion of Miwa [2008], focusing on the movement of the ratio of change in short-term bank borrowing to total asset, that we find no clear sign of serious "credit crunch" applies also to the situations where we focus on other financial variables like receivables, payables, and inventory and expand our examination to small businesses.

Dramatic decrease in the difference variable in payables, particularly for $v 4=8$, in the $3^{\text {rd }}$ quarter of FY2008, immediately after the Lehman Shock is prominent.

The above has little modification as I limit the examination to the manufacturing sector.

\section{Fruitful Result of the Government's Appropriate and Effective Policy Response?}

Not a few readers might think: "Even if we find no remarkable observation to be judged as a clear sign of serious 'credit crunch' and 'financial crisis', it might be a fruitful result of the government's appropriate and effective policy response. Wouldn't it an overstatement to say that it raises even a strong doubt about the potential severity of the financial crisis?" 
First of all, readers should ask themselves: "what is the specific nature of the 'government's appropriate and effective policy response'?" and "have I ever seen persuasive logical grounds and evidence of the claim that it worked effectively?" Note that, both now and then, what reaches our ears is mostly voices either of parties concerned like bureaucrats in relevant government sections and those in financial institutions and of newspersons supposed to monitor them at a close range. In Japan, where rarely the specific details of policy decision-making is disclosed in public, nothing other than those voices of parties concerned remains lodged in public's brain in ten years for instance. Readers should ask themselves also: "how did the public, including depositors and borrowing firm's managers, expect the behavior and policy response of the government for prevention and avoidance of financial institution's failures and for avoiding 'crisis' and 'confusion' accompanied by their failures, and also the behavior of financial institutions and the movement in the financial market? How did they prepare and respond?"

At this time, financial institutions including big ones, alleged never to fall into bankruptcy, went bankrupt in sequence. It took almost a year for the policy debates that got active in parallel with those events settled and enforced. This period is widely recognized as the peak of the "Heisei Financial Crisis", when "financial issues" were of particular interest both to the media and to the public. It was impossible, in terms of both the depositors and borrowers, neither experienced anxiety nor generated disruption, upon an overwhelming reliability on the government's appropriate and effective policy responses.

With the collapse of Yamaichi Securities on the 22nd November, 1997, following the failure of Sanyo Securities on the 3rd and of Hokkaido Takushoku Bank on the 17th, the "financial crisis" reached full force in Japan, and that of Tokuyo City Bank on the 26th. On December 5, the Ministry of Finance announced to protect all the bank deposits and financial bonds until March 2001. On 12 January 1998, Prime Minister Hashimoto declared in his speech to Congress that Japan would not trigger a global financial panic. The government was forced to take the control both of the Long Term Credit Bank of Japan on 23 October 1998 and of the Bond Credit Bank of Japan on December 13. It was on 12 March 1999 when the Financial Revitalizing Committee, created on 5 December 1998, decided the injection of public funds, $¥ 7.4592$ trillion in total, to 15 banks. Even if the infusion worked well and played a critical role, already one year and four months had passed since November $1997 .{ }^{17}$

The Japanese economy, firm's financing behavior of the time in particular, offers an

\footnotetext{
${ }^{17}$ For more details, see the "Time-line of Events on Financial System: 1965-2002" in Nishimura [2003, pp.458-61]. For a brief review of the process, see Miwa [2008, pp.6-8]. Reader should ask carefully: "Did the public fund injection work effectively and greatly contribute to the "financial stability'?" and "Did this injection improve the national welfare?" If the "disorder" and the "diagnosis and treatment" targeted (or alleged to target) were negligible or non-existent, the performance evaluation of the treatment would be minor (or negative).
} 
intriguing "laboratory" to study the borrowers' behavior in response to the realization process to bank failures of lending financial institutions including big banks. It is an "experimental" opportunity to obtain valuable information for grave agenda: "how borrowing firms prepare and respond to the possible failure of individual banks and 'confusion', often called a 'systemic risk', on the diffusion process that follows the failures." The individual bank's response to borrowers is either not uniform. Firm's response, optimizing behavior under constraints, must be non-uniform, and we could expect to obtain information about the determinants of firm's responding behavior.

The conventional wisdom on which the research at the start was designed deviated substantially from the reality, however. Concerning the "financial crisis" and "credit crunch" at the end of the 1990s, it overestimated the consequences of financial institutions failures including big banks. Upon this overestimation, the government made every effort for avoiding bank failure to occur, delaying the adoption of necessary policies. On top of that, with almost no preparations (because the government intended to emphasize that there was no possibility of bank failures, particularly of big banks, or used it as an excuse), Japan climaxed with a sequence of bank failures and confusion in policy responses. It resulted in a "crisis" and "panic" in financial institutions and financial administration, with which people in and around the "panic", particularly the media and academics including "Japanese government watchers", were quite impressed.

Investigation on financing behaviors of firms under the "financial crisis" from the end of 1997 to the beginning of 1999 indeed suggest that it was a fiasco caused by the confusion of a "crisis of financial institutions" with a "financial crisis". Similarly, the failure possibility of financial institutions including jusen housing loan companies, big financial institutions in particular, and also the severity of "confusion" that follows the failures might have been significantly overestimated, and intentionally exaggerated. The cost that an often-stressed expression, "too big to fail", assumes might have been left un-estimated due to the false assumption that is simply a "myth". 18

\section{Zero-bank-borrowing Firms vs. Positive-bank-borrowing Firms}

It must not be only the present author that was surprised and shocked at the findings: (1) In so many firms the outstanding amount of short-term-bank-borrowings was zero $\left(\mathrm{y}_{\mathrm{t}-1}^{1}=0\right)$, and its ratio to the total was higher in smaller firm size classes; (2) The number of such zero-short-term-borrowing firms increased under the recent "zero-interest-rate, quantity easing"

\footnotetext{
${ }^{18}$ Readers who wonder that, although so many like to refer to the phrase, "too big to fail", too few go into its details and necessary measures for its prevention should see John Kay [2009] and Taylor [2010]. For the definition and identification of SIFIs (systemically important financial institutions) which recently we see frequently, see Jackson [2010], Stroebel [2010].
} 
monetary policy, the ratio of which today to the level of $2 / 3$ in the smallest-size firms class. Not a few readers would be interested in a forward-looking question: "There must be an essential difference between 'zero-bank-borrowing' firms and 'positive-bank-borrowing' firms, from which we would obtain valuable information for understanding the reality of the financial market." The second half of Miwa [2010d] investigated along this question.

In [III-4] [III-7], as the first step of investigating the relationships among relevant variables, I compare the two groups of firms, firms with positive-short-term-bank-borrowing at the beginning of the quarter (type $\mathrm{A}, \mathrm{y}_{\mathrm{t}-1}^{1}>0$ ) and firms with zero-short-term-bank-borrowing (type $\mathrm{B}, \mathrm{y}_{\mathrm{t}-1}^{1}=0$ ). It is based on the expectation that there is an essential difference between two types of firms, which is revealed in firm's choice, so that through comparison we will obtain useful information and hints for future research on the decision mechanism on short-term bank borrowing and the causality in making decisions concerning financial variables. It is to seek a clue to think: "is it because they could not obtain loans from banks? or they did not take it?" "what factors their decision depends?"

I find no prominent difference in any individual items between two firm groups. For example, no prominence difference became obvious during the "credit crunch" in 1997-1999 or the "financial crisis" of 2007.

Comparison of firms with positive-short-term-bank-borrowing at the beginning of the quarter (type A) and firms with zero-short-term-bank-borrowing (type B):

Distribution of individual item's composition ratio $\left(l_{t}^{i}\right)$

[III-4] and [III-5] focus on the individual item's composition ratio (level variables, $1_{\mathrm{t}}^{\mathrm{i}}$ ), and [III-6] and [III-7] on the difference variables $\left(\mathrm{d}_{\mathrm{t}}^{\mathrm{i}}\right)$.

The following refers two figures on the distribution of payable dependence ratio (Figure 10a and Figure 10b, $1^{5}$ ), for all firms surveyed in all industries, and their comparison table (Table 8, III-4-4). 

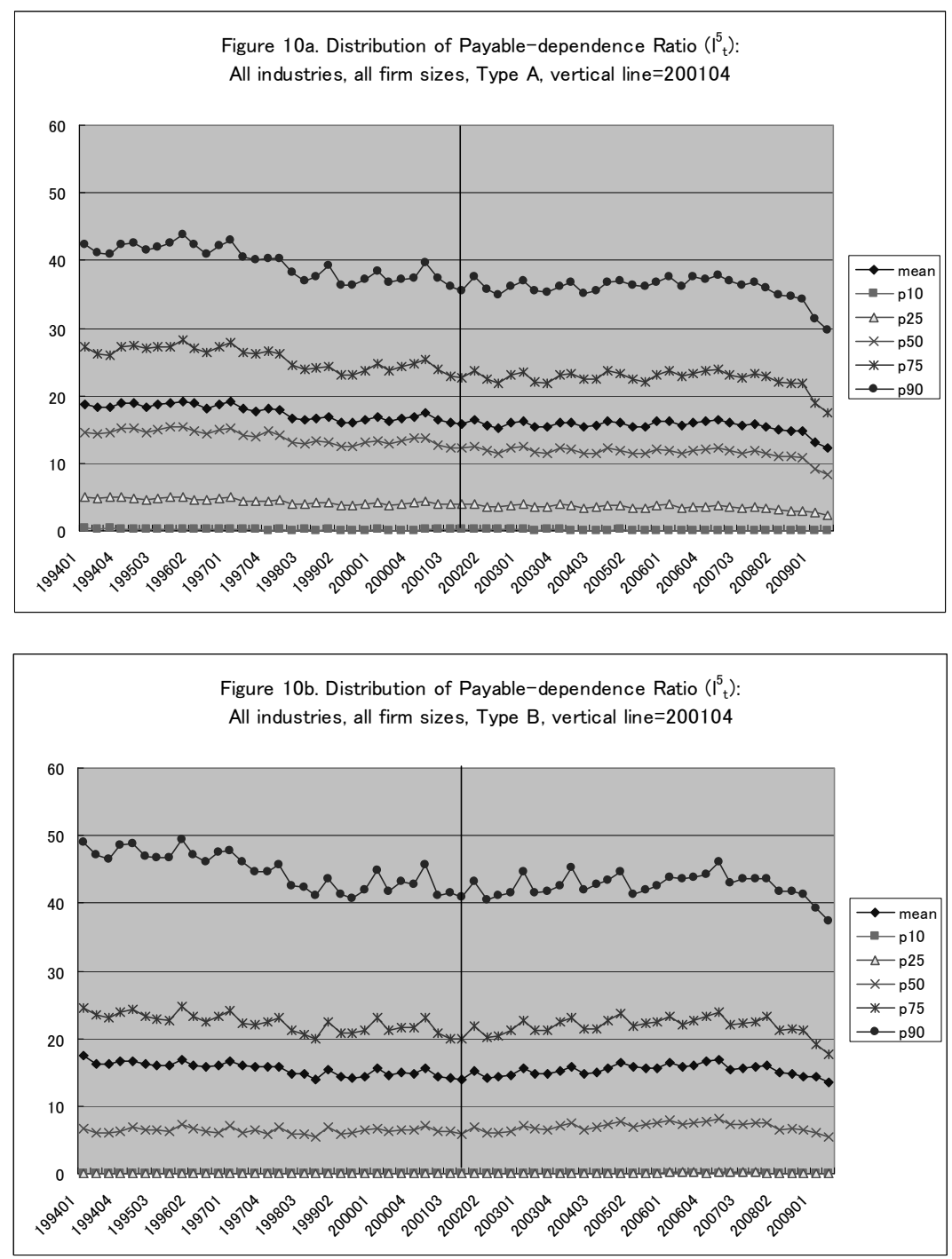

Table 8. Distribution of payable-dependence ratio $\left(\mathrm{I}_{\mathrm{t}}^{5}\right)$ : Comparison of firms in Type $A$ and Type B:

\begin{tabular}{|c|c|c|c|c|c|c|c|}
\hline & & mean & $\mathrm{p} 10$ & $\mathrm{p} 25$ & p50 & p75 & p90 \\
\hline \multirow{4}{*}{$\begin{array}{l}\text { Firms with non-zero-short- } \\
\text { term-bank-borrowing } \\
\text { at the beginning of the quarter } \\
\text { (A) }\end{array}$} & Average 1 & 17.53 & 0.21 & 4.38 & 13.86 & 25.48 & 39.64 \\
\hline & Average 2 & 15.49 & 0.10 & 3.48 & 11.54 & 22.49 & 35.83 \\
\hline & Average $\mathrm{T}$ & 16.54 & 0.15 & 3.94 & 12.74 & 24.03 & 37.80 \\
\hline & Av. $1-A v .2$ & 2.04 & 0.11 & 0.89 & 2.32 & 2.98 & 3.81 \\
\hline \multirow{4}{*}{$\begin{array}{l}\text { Firms with zero-short-term- } \\
\text { bank-borrowing } \\
\text { at the beginning of the quarter } \\
\text { (B) }\end{array}$} & Average 1 & 15.46 & 0.00 & 0.00 & 6.34 & 22.30 & 44.84 \\
\hline & Average 2 & 15.30 & 0.00 & 0.07 & 6.95 & 21.83 & 42.57 \\
\hline & Average $T$ & 15.39 & 0.00 & 0.03 & 6.64 & 22.07 & 43.75 \\
\hline & $A v .1-A v .2$ & 0.16 & 0.00 & -0.07 & -0.61 & 0.47 & 2.27 \\
\hline \multirow{4}{*}{$(A)-(B)$} & Average 1 & 2.07 & 0.21 & 4.38 & 7.52 & 3.18 & -5.20 \\
\hline & Average 2 & 0.18 & 0.10 & 3.41 & 4.59 & 0.66 & -6.74 \\
\hline & Average $\mathrm{T}$ & 1.15 & 0.15 & 3.91 & 6.10 & 1.96 & -5.95 \\
\hline & Av.1-Av.2 & 1.88 & 0.11 & 0.96 & 2.93 & 2.52 & 1.54 \\
\hline
\end{tabular}


Next is the "particularly prominent observations" in [III-4] for all industries (III-4-1).

(1) Both in all industries and in the manufacturing industry, there is a remarkable difference between two groups of firms in the level of the ratio of deposit to total asset, particularly in p50, p75, p90, and the mean value. This pattern has consistently continued over the study period. However, for instance the p50 value of type B falls far short of the p75 value of type A, which shows that not all the type B firms hold higher ratio (to total asset) of deposit than all the type A firms.

(2) There is a prominent difference between two types of firms in long-term bank dependence ratio. In addition, concerning the type $\mathrm{B}$ firms there is a noteworthy difference between the first half and the second half of the period. (We executed comparison by firm size of the distribution of long-term bank dependence ratio in [I-2-4] for all industries, and in [I-3-2] for the manufacturing industry.) Particularly for the type B large firms, the long-term bank dependence ratio decreased dramatically in the second half period.

(3) Rather we had better pay the prime attention to the observation that there is no difference between two types of firms, concerning receivable, payable, and inventory. In addition, there is no difference in that distribution pattern remains stable throughout most of the study period and that during the period of recent "financial crisis" both ratios of receivable and payable (but not inventory) decreased dramatically.

Comparison of firms with positive-short-term-bank-borrowing at the beginning of the quarter (type A) and firms with zero-short-term-bank-borrowing (type B):

Distribution of change in individual item's composition ratio $\left(d_{t}{ }_{t}\right)$

[III-6] and [III-7] examine the distribution of change in individual item's composition ratio, comparing two groups of firms, firms with positive-short- term-bank-borrowing at the beginning of the quarter (type $A, y^{1}>0$ ) and firms with zero-short-term-bank-borrowing (type $\mathrm{B}$, $\mathrm{y}_{\mathrm{t}}^{1}=0$ ). Basically, examination methods are the same as the ones adopted for $1_{\mathrm{t}}^{\mathrm{i}}$ in [III-4] and [III-5].

For illustration, here as well I introduce two figures on the distribution of change in payable dependence ratio (Figure 11a and Figure $11 \mathrm{~b}, \mathrm{~d}_{\mathrm{t}}^{5}$ ), for all firms surveyed in all industries, and their comparison table (Table 9, III-6-4). 

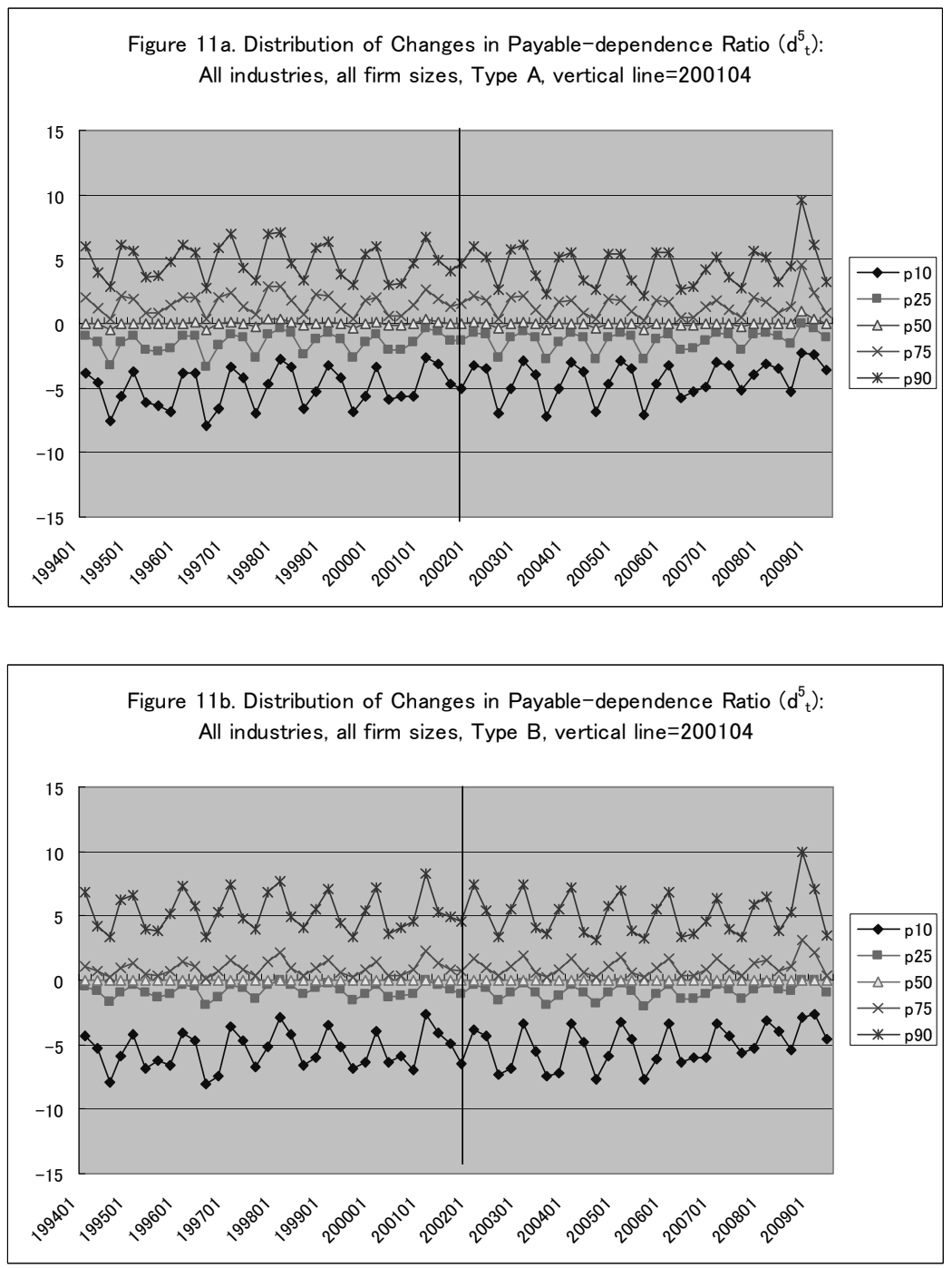

Table9. Distribution of changes in payabl- dependence ratio $\left(\mathrm{d}_{t}^{5}\right)$ : Comparison of firms in Type A and Type B: all industries, all size firms, unit $=\%$

\begin{tabular}{|c|c|c|c|c|c|c|}
\hline & & $\mathrm{p} 10$ & p25 & p50 & p75 & p90 \\
\hline \multirow{4}{*}{$\begin{array}{c}\text { Firms with non-zero-short- } \\
\text { term-bank-borrowing } \\
\text { at the beginning of the quarter } \\
\text { (A) }\end{array}$} & Average 1 & -5.00 & -1.48 & -0.01 & 1.56 & 4.86 \\
\hline & Average 2 & -4.30 & -1.25 & -0.02 & 1.40 & 4.47 \\
\hline & Average $T$ & -4.66 & -1.37 & -0.01 & 1.48 & 4.67 \\
\hline & $A v .1-A v .2$ & -0.70 & -0.22 & 0.02 & 0.16 & 0.39 \\
\hline \multirow{4}{*}{$\begin{array}{l}\text { Firms with zero-short-term- } \\
\text { bank-borrowing } \\
\text { at the beginning of the quarter } \\
\text { (B) }\end{array}$} & Average 1 & -5.46 & -0.82 & 0.00 & 0.92 & 5.31 \\
\hline & Average 2 & -5.06 & -0.87 & 0.00 & 1.04 & 5.20 \\
\hline & Average $\mathrm{T}$ & -5.27 & -0.84 & 0.00 & 0.98 & 5.26 \\
\hline & Av.1 - Av.2 & -0.40 & 0.05 & 0.00 & -0.12 & 0.11 \\
\hline \multirow{4}{*}{$(A)-(B)$} & Average 1 & 0.46 & -0.66 & -0.01 & 0.64 & -0.45 \\
\hline & Average 2 & 0.76 & -0.39 & -0.02 & 0.36 & -0.73 \\
\hline & Average $T$ & 0.60 & -0.53 & -0.01 & 0.51 & -0.58 \\
\hline & $A v .1-A v .2$ & -0.30 & -0.27 & 0.02 & 0.28 & 0.28 \\
\hline
\end{tabular}




\section{Concluding Remarks and Interesting Observations from the Research}

This paper is based on a part of my previous research on Japanese firm's financing behavior using firm-level CEQStat data.

Firms have maintained a dependence on financial institutions (=borrowings from financial institutions/total assets) well below the level that the conventional wisdom has claimed, which further fell drastically in recent years, particularly in the $21^{\text {st }}$ century under the "zero-interest-rate, quantity easing" monetary policy (in this paper, I call those phenomena "ginko-banare", or "independence of the firms from banks".

Keeping this "independence of the firms from banks" in mind, I investigated the financing behavior of Japanese firms during the period from the end of 1997 to the beginning of 1999 and found no prominent phenomena as clear signs of "financial crisis" or "credit crunch". In addition, no persuasive ground is found, either logical foundation or evidences, that support the conventional wisdom that a severe "credit crunch" occurred during this period in Japan. It was a fiasco caused by the confusion of a "crisis of financial institutions" and "financial administration" with "financial crisis".

What is critically important here is that CEStat, CEQStat in particular, that provides relevant statistical information by far of the best quality, has rarely been used effectively in research on financial phenomena or policy debates. Instead, the conventional wisdom that financial institutions, big banks in particular, have dominated the Japanese financial market and played there the key roles has long been an obvious basic assumption in researches and policy debates over the Japanese financial phenomena. As shown above, this conventional wisdom, which has been widely accepted, although upon scant grounds, is a misconception, a myth substantially deviating from the reality, implying that both the academic researches and policy debates that have long dominated the fields are "house of cards" or "mirage".

In light of the position the conventional wisdom still occupies now, the most basic message of this research might be that CEQStat which provides relevant statistical information by far of the best quality, particularly about small business firms, has rarely been used effectively in research on financial phenomena or policy debates, and that its active use is an effective way out of the present miserably confusing situation.

As mentioned above in Section I, this article is based on a part of my previous research. Although it is an important part, it is just around the entrance. It is my hope that readers who got interested in this paper entitled, "Are Japanese Firms Becoming More Independent from Their Banks?", proceed to the whole research including its problem settings and used data.

As a consequence of the basic character, this research draws few clear "conclusions" directly, and it does not fit in so easily with "summary". Instead, I list below points and observations that I found impressive on the process of the study and still interests me at its close, which I believe useful for readers in understanding behavior of Japanese firms, small 
businesses in particular, and information organized in the report.

(1) Even when I focus only on financing (and asset allocation), the behavior of firms in Japan ranges widely. Together with "representative figures" obtainable also from summary statistics published as the result of CEStat (CEAStat and CEQStat) surveys, particularly for understanding the reality of great diversity in Japanese firms we should promote mote active utilization of firm-level data from those statistics.

(2) In light of the low bank dependence ratio (much lower than the conventional wisdom has claimed), the relationship between bank's lending- and firm's borrowing behavior is by far remoter than has been widely assumed. The analytical method, that has been a foundation of the conventional wisdom, adopts the information about bank's lending behavior as a good substitute of firm's borrowing behavior, implicitly assuming either one-to-one correspondence or virtual integration. It has been a source of misunderstanding and a cause of big troubles. Examination of firm's financing and asset allocation behavior, too, must be conducted upon exact reality of examination objects.

(3) With the exception of listed firms for which security filings are available, CEStat is about the only source that provides good statistical information about firms including small businesses in Japan. Nevertheless, CEStat including the published summary statistics has rarely been utilized in researches and policy debates on financial phenomena and finance related policies including small business policies. As a result, the conventional wisdom that has been a foundation of those researches and policies is a misconception, misunderstanding, or a myth substantially deviating from the reality. Not only such a situation has been left as it is but also it has faced with few serious challenge or sense of crisis.

(4) The evil of the above (3) is particularly serious concerning small business. In Japan, small businesses have received special treatment in a world of this "myth". Recent heated policy discussion (or fiasco) over the "bank's reluctance to small business lending" and rapid expansion of related policies are symbolic. Unsurprisingly, neither coherent logical explanation nor persuasive evidence is presented.

(5) What is the most surprising and impressive in this research is the Japanese firm's low degree of dependence on banks (to be precise, financial institutions), the ratio of bank borrowing, short-term borrowing in particular, to total asset. Even in the 1960s, the bank dependence ratio was by far lower than has been claimed by the conventional wisdom, and since then it has consistently decreased to the present. I think that it is appropriate to call it "low bank dependence" and "further increase in independence of firms from banks". I was truly surprised to find that this "increase in independence" has accelerated under the ultra-easy credit policy under "zero-lending-rate" in the 2000s and that these "low bank dependence ratio" and "further increase in independence from 
banks" have been more prominent among small businesses than among ultra-big excellent companies that are alleged to be advantageous in making access to international capital market.

(6) With the sole exception of receivable-payable relations (stable high positive correlation coefficient is symbolic), the study of inter-relations among composition variables such as short-term borrowing, long-term borrowing, deposit, receivable, payable, and inventory shows no noteworthy strong relation. Moreover, it is impressive that such inter-relationship is observed stably throughout the study period. No long-term changing trend is observed. No prominent change is observed during the "credit crunch" in 1997-1999 and the "financial crisis" of 2007, either.

(7) The above (6) with little modification applies also to the study of inter-relations among changes in composition ratios. I expected to find prominent phenomena that had emerged in response to "outside shocks" during the "credit crunch" in 1997-1999 or in the "financial crisis" of 2007, which would be useful in understanding the inter-relations among changes in composition ratios. Unfortunately, however, no such prominent phenomena recognized to be a sign of those shocks. Of the points (6) and (7), I was more deeply surprised at the stability of inter-relations among changes in composition ratios.

(8) Concerning any of short-term borrowing, long-term borrowing, and total borrowing (sum of short-term- and long-term borrowing), there is no close relationship with other financial variables studied in this research. For example, there is no observation that suggests an often-claimed relation that firms finding difficulty in obtaining bank borrowing actively use payables as its alternative funding source.

(9) We have little information about trade credit, both detailed basic information and explanations on its transaction. Under such a situation, the view that "trade credit is used primarily for inventory finance" has been accepted as the conventional wisdom. This view, however, is obscure and vague, whose substance is almost completely unclear. Investigation on the basis of CEStat shows that, whatever the interpretation, this conventional wisdom is not supported by the data.

(10) Of inter-relationships among receivable, payable, and inventory, the relation between receivable and payable is strong and stable, but the one between inventory and receivable or payable is neither strong nor stable. The conventional wisdom has long argued, "trade credit is the means for large companies that enjoy advantages in bank borrowing to supply credit to small businesses". Data from the CEStat do not support this view, either in the study period of FY1994-FY2009 or in several decades since the 1960s.

(11) The research covers the period when the financial market since the burst of "Bubble" has been like a roller-coaster and experienced a series of close encounters with new 
unknown phenomena. Observers consistently criticized that the various troubles and slow response in related policies have been an important cause of the "Lost Two Decades". On various fronts, I was often surprised to see a weak (or no) correspondence between observations drawn from data and the widely accepted "facts". Most symbolically, I did not find serious impacts of the "credit crunch" in 1997-1999 on firm's financing behavior, including that of the impact of actual collapse of several financial institutions which had been alleged to be so grave.

(12) Heated discussion and prominent expansion of small business policies symbolizes the Japanese economy during the past two decades since the burst of "Bubble", the so-called "Lost Two Decades". Emphasizing the seriousness of "banks' reluctance to small business lending" and its decisive importance to the Japanese economy, the Japanese government expanded small business policies on a historically unprecedented scale and scope, at the center of which is the "credit guarantee policy". In none of its necessity, importance as policy issue, and effectiveness and efficiency of the policy that ensures its continuous implementation, either coherent logical explanation or persuasive evidence is available. It is not easy to draw grounds to support any of them from the study of firm's financing (asset allocation) behavior using firm-level data from the CEQStat. 


\section{References}

Hoshi, Takeo and Anil Kashyap [2001] Corporate Financing and Governance in Japan: The Road to the Future, The MIT Press.

Ito, Takatoshi [1992] The Japanese Economy, The MIT Press.

Ito, Takatoshi [2000] "The Stagnant Japanese Economy in the 1990s: The Need for Financial Supervision to Restore Sustained Growth," in Hoshi, Takeo and Hugh Patrick eds. [2000] Crisis and Change in the Japanese Financial System. Boston: Kluwer Academic.

Jackson, Thomas H. [2010] "Chapter 11F: A Proposal for the Use of Bankruptcy to Resolve Financial Institutions," in Scott et al eds. [2010].

Kay, John [2009] "'Too big to fail' is too dumb to keep", Financial Times, Oct. 28.

Miwa, Yoshiro [2008] “'Credit Crunch"?: Details from Borrower Quarterly Financial Data about What Actually Happened in Japan during 1997-1999”, CIRJE-J-202, August, (in Japanese).

Miwa, Yoshiro [2010a] "'Credit Guarantee' Policy [shin'yo hosho seido] for Small Businesses in Japan, with Reference to 'the Special Guarantee Policy' during 1998.10 2001.3", Keizaigaku ronshu (The Journal of Economics of the University of Tokyo), 76-2, 3, (in Japanese).

Miwa, Yoshiro [2010b] “A Study of Financing Behavior of Japanese Firms with Firm-Level Data from Corporate Enterprise Quarterly Statistics - 1994 2009: Introduction and Summary”, CIRJE-J-222, (DPI\&S, in Japanese).

Miwa, Yoshiro [2010c] 'The Low 'Bank-Dependence Ratio' and the Further Increase in the 'Independence of Firms from Banks"', CIRJE-J-223, (DP1, in Japanese).

Miwa, Yoshiro [2010d] "The Reality of Short-term Shocks like the 'Credit Crunch' of 1997-1999 and the 'Financial Crisis' of 2007, and the Effectiveness of 'Emergency' Economic Measures - A Follow-up to Miwa [2008]”, CIRJE-J-224, (DP2, in Japanese).

Miwa, Yoshiro [2010e] "The Reality of Trade Credit and its Link to Bank Borrowing and Inventory: (1) Overall Discussion and Preliminary Investigation”, CIRJE-J-225, (DP3, in Japanese).

Miwa, Yoshiro [2010f] "The Reality of Trade Credit and its Link to Bank Borrowing and Inventory: (2) Correlation Coefficients and Multiple Regressions", CIRJE-J-226, (DP4, in Japanese).

Miwa, Yoshiro [2011a] "A Study of Financing Behavior of Japanese Firms with Firm-Level Data from Corporate Enterprise Quarterly Statistics - 1994 2009: Introduction and Summary," CIRJE-F-785.

Miwa, Yoshiro [2011b] “Are Japanese Firms Becoming More Independent from Their Banks? Evidence from the Firm-Level Data from the 'Corporate Enterprise Quarterly Statistics,' 1994-2009”, Financial Review (of the Ministry of Finance), No.107, May (in Japanese). 
Miwa, Yoshiro [2011c] "The Financing Behavior by Small Firms, and Small-firm Loans by Banks," Keizaigaku ronshu (The Journal of Economics of the University of Tokyo), 76-2, 3, (in Japanese).

Miwa, Yoshiro [2011d] “'Bad-Loan', 'Delay in its Disposal', 'Oigashi or Zombie Lending', and the 'Lost Two Decades': Lessons from the Japanese Experience?" Keizaigaku ronshu (The Journal of Economics of the University of Tokyo), 76-2, 3, (in Japanese).

Miwa, Yoshiro and J. Mark Ramseyer [2001] Misunderstandings in the Theory of the Japanese Economy: Liberation from the Spell of the "Keiretsu”, Tokyo: Toyo keizai shimpo-sha, (in Japanese).

Miwa, Yoshiro and J. Mark Ramseyer [2004] "Directed Credit? The Loan Market in High-Growth Japan," Journal of Economics and Management Strategy, 13, pp.171-205.

Miwa, Yoshiro and J. Mark Ramseyer [2006] The Fable of the Keiretsu: Urban Legends of the Japanese Economy, The University of Chicago Press.

Miwa, Yoshiro and J. Mark Ramseyer [2007] Using Economics - An Introduction to the Empirical Study of the Japanese Economy, Nihon hyoron-sha, (in Japanese).

Miwa, Yoshiro and J. Mark Ramseyer [2008] "The Implication of Trade Credit for Bank Monitoring: Suggestive Evidence from Japan," Journal of Economics and Management Strategy, 17-2, pp.317-43.

Scott, Kenneth E., George P. Schultz, and John B. Taylor eds. [2010] Ending Government Bailouts: As We Know Them, Hoover Institutions Press.

Stroebel, Johannes [2010] "A Summary of the Commentary," in Scott et al eds. [2010].

Taylor, John B. [2010] “Defining Systemic Risk Operationally,” in Scott et al eds. [2010]. 
